\title{
Metformin suppresses breast cancer growth via inhibition of cyclooxygenase-2
}

\author{
BIN SHI $^{1,2^{*}}$, XINYU HU ${ }^{1 *}$, HUIMIN HE $^{1}$ and WENZHENG FANG ${ }^{1 *}$ \\ ${ }^{1}$ Department of Medical Oncology, Fuzhou General Hospital of Fujian Medical University, East Hospital \\ Affiliated to Xiamen University (The 900th Hospital of The Joint Logistics Support Force of The Chinese PLA), \\ Dongfang Hospital, Xiamen University, Fuzhou, Fujian 350025; ${ }^{2}$ Department of Medical Oncology, \\ Longyan People's Hospital, Longyan, Fujian 364000, P.R. China
}

Received September 11, 2020; Accepted May 26, 2021

DOI: $10.3892 / \mathrm{ol} .2021 .12876$

\begin{abstract}
Pre-clinical and on-going trials have indicated the advantage of using metformin as an anticancer drug alone or in combination with other chemotherapeutics for the treatment of patients with breast cancer. However, the mechanisms by which metformin attenuates tumorigenesis remain to be further elucidated. The present study investigated the anticancer effects of metformin in breast cancer and identified potential molecular targets of metformin using western blotting and immunohistochemical analysis. Metformin significantly decreased tumor cell proliferation in vitro and suppressed tumor growth in vivo. Moreover, it induced the activation of AMP-induced protein kinase and suppression of phosphorylated-eukaryotic translation initiation factor 4E-binding protein 1 (p-4E-BP1), a downstream effector of the mTOR signaling pathway, and decreased cyclin D1 levels in in vitro and in vivo experimental models. Additionally, metformin inhibited cyclooxygenase (COX)-2 expression. Clinically, high expression levels of COX-2 and p-4E-BP1 in tissues of patients with breast cancer were significantly associated with enhanced lymphatic metastasis and distant metastasis. Thus, the current data suggested that metformin
\end{abstract}

Correspondence to: Dr Bin Shi, Department of Medical Oncology, Longyan People's Hospital, 31 Denggao West Road, Longyan, Fujian 364000, P.R. China

E-mail: doctorbinshi@aliyun.com

Professor Wenzheng Fang, Department of Medical Oncology, Fuzhou General Hospital of Fujian Medical University, East Hospital Affiliated to Xiamen University (The 900th Hospital of The Joint Logistics Support Force of The Chinese PLA), Dongfang Hospital, Xiamen University, 156 West Second Ring North Road, Fuzhou, Fujian 350025, P.R. China

E-mail: doctorwenzheng@aliyun.com

${ }^{*}$ Contributed equally

Key words: breast carcinoma, metformin, AMP kinase, mTOR, cyclooxygenase-2 may have potential value as a synergistic therapy targeting both the COX-2 and mTOR signaling pathways.

\section{Introduction}

Breast cancer is the most common malignancy in women and the most common cause of cancer-associated death among women worldwide (1). Advances in early detection and cancer therapy have led to a reduction in the incidence of breast cancer, and breast cancer-associated deaths have decreased by $2 \%$ in the past decade (2). However, the prognosis of patients varies greatly and is affected by numerous factors, including tumor type, stage, treatment and geographical location; for example, prognosis is better among patients in Western countries than among those in developing countries (3). Furthermore, a higher stage at diagnosis is associated with a poorer prognosis; stage 0 ductal carcinoma in situ has an excellent prognosis with a 10 -year survival rate of $\sim 98 \%$, while stage IV metastatic cancer has a poor prognosis with a 10 -year survival rate of $<10 \%$ (4). This discrepancy poses a substantial clinical challenge. Thus, it is necessary to identify novel molecular targets and drugs that will strengthen early intervention and effective therapeutic strategies.

Several studies have indicated that patients with type 2 diabetes mellitus (DM) have an increased risk for the development of several types of cancer, including breast cancer (5-11). Metformin is a first-line drug for type $2 \mathrm{DM}$, and numerous studies have demonstrated that it is associated with a lower risk of breast cancer in patients with type 2 DM (12-15). Metformin inhibits the proliferation and colony formation of cancer cells by inducing cell cycle arrest and apoptosis by modulating the expression levels of proteins that regulate the $G_{1}-S$ cell cycle transition, including cyclin D1, cyclin E1 and E2F transcription factor $1(12,16-18)$. The AMP kinase (AMPK) regulatory system is one of the main targets of metformin therapy (19). The activation of AMPK regulates tumor cell survival and tumor growth through inhibition of the mTOR and fatty acid synthesis signaling pathways, and it also stimulates the apoptotic pathway (p53/p21 axis) $(14,20,21)$. However, the precise molecular mechanisms of metformin in breast cancer remain to be fully elucidated. 
Cyclooxygenase-2 (COX-2) is expressed in numerous types of solid tumor tissues and cells, and serves a key role in the development of breast cancer $(22,23)$. COX-2 expression is upregulated in $\sim 50 \%$ of breast cancer cases, and high COX-2 expression is significantly associated with a poor clinical outcome (24-27). COX-2 is associated with increased proliferation and angiogenesis in human breast cancer $(28,29)$. Furthermore, COX-2 increases the production of prostaglandin E2 (PGE2), which stimulates breast cancer progression and bone metastasis (30-32). Therefore, COX-2 inhibitors may have a role in the prevention and treatment of breast cancer, and may have value as novel biomarkers to stratify breast cancer risk in women with atypia (33). Non-steroidal anti-inflammatory drugs (NSAIDs), particularly the highly selective COX-2 inhibitors, have been shown experimentally to stimulate apoptosis and inhibit angiogenesis, two mechanisms that can counteract tumor growth, progression and metastasis (34). In addition to NSAIDs, administration of metformin can prevent the increase in COX-2 expression induced by dehydroepiandrosterone and enhance the activation of phosphorylated (p)-AMPKa expression in embryonic ovarian disorders $(35,36)$. While the aforementioned studies have confirmed an association of high COX-2 expression with highly aggressive tumors and have emphasized the anticancer action of metformin in breast cancer, the underlying mechanisms remain unclear.

The present study provided preliminary evidence that metformin inhibited breast cancer cell proliferation via the well known AMPK/mTOR signaling pathway and the novel AMPK/COX-2 signaling pathway.

\section{Materials and methods}

Clinical samples. Between January 2016 and December 2018, 63 patients with invasive breast cancer that underwent curative surgical resection at the Changhai Hospital (Shanghai, China) and Kunshan Hospital (Jiangsu, China) were enrolled in the present study. Tumor and adjacent normal tissues from patients with breast cancer were obtained and the expression levels of AMPK/COX-2/mTOR signaling proteins were analyzed. Non-tumor specimens were $\geq 1.5 \mathrm{~cm}$ from the tumor margins. All 63 patients were female and aged between 38 and 78 years (mean age \pm SD, $50.5 \pm 6.7$ years). A total of $29(46.0 \%)$ and $34(54.0 \%)$ patients were aged $<50$ years and $>50$ years, respectively. The tumors were staged following the tumor-node-metastasis (TNM) staging system of the International Union Against Cancer (37). A total of 53 (84.1\%) tumors were categorized as stage I-II and $10(15.9 \%)$ tumors as stages III-IV. None of the patients received preoperative chemotherapy and/or radiation therapy. Freshly resected tissues from patients with breast cancer were immediately snap-frozen in liquid nitrogen. All the clinical specimens were obtained with written informed consent, and the Institutional Review Boards of the Affiliated Kunshan First People's Hospital of Jiangsu University and Changhai Hospital approved the use of all tissues and clinical information (approval no. CHEC2014-098).

Reagents and antibodies. Metformin (cat. no. 1115-70-4) was purchased from Sangon Biotech Co., Ltd. Antibodies against p-AMPK $\alpha$ (Thr-172 or D4D6D; cat. no. 50081), AMPK $\alpha$
(D5A2; cat. no. 5831), p-eukaryotic translation initiation factor 4E-binding protein 1 (p-4E-BP1; Thr-37/46; cat. no. 2855), 4E-BP1 (53H11; cat. no. 9644), COX-2 (D5H5; cat. no. 4842) and Cyclin D1 (E3P5S; cat. no. 55506) were purchased from Cell Signaling Technology, Inc. Anti-proliferating cell nuclear antigen (PCNA) antibody (EPR3821; cat. no. ab92552) and anti-PGE2 antibody (cat. no. ab45295) were obtained from Abcam. Anti- $\beta$-actin (C4; cat. no. sc-47778) was obtained from Santa Cruz Biotechnology, Inc.

Cell culture. The breast cancer MCF-7 and 4T1 cell lines were purchased from the Cell Bank of Type Culture Collection of the Chinese Academy of Sciences. Both cell lines were grown in DMEM (Invitrogen; Thermo Fisher Scientific, Inc.) with 10\% FBS (Invitrogen; Thermo Fisher Scientific, Inc.). The cell lines were kept at $37^{\circ} \mathrm{C}$ in a humidified incubator with $5 \% \mathrm{CO}_{2}$.

MTT assay. The MTT assay was used to assess the anti-proliferative effects of metformin in MCF-7 and 4T1 cells. In recent years of breast cancer research, the dosage range of metformin has been $1-50 \mathrm{mM}$, and the highest dosage can reach $100 \mathrm{mM}(38,39)$. It has been reported that metformin can induce the AMPK signaling pathway in the dose range of $10-20 \mathrm{mM}$, thereby increasing apoptosis (40). Therefore, metformin with the dose range of $20-50 \mathrm{mM}$ was selected to study its antitumor mechanism. Exponentially growing cells were trypsinized, counted and plated at $5 \times 10^{3}$ cells/well in 96-well plates. After $24 \mathrm{~h}$, cells were treated with 0,20 or $50 \mathrm{mM}$ metformin for $24,48,96$ or $144 \mathrm{~h}$. Thereafter, the medium was changed, and the cells were incubated with $10 \mu \mathrm{l}$ MTT (Sigma-Aldrich; Merck KGaA; $5 \mathrm{mg} / \mathrm{ml}$ ) at $37^{\circ} \mathrm{C}$ for $4 \mathrm{~h}$ before each test. The supernatant was then carefully discarded, and $150 \mu 1$ DMSO (Sigma-Aldrich; Merck KGaA; cat. no. D2650) was added to dissolve the precipitate. Absorbance at $490 \mathrm{~nm}$ (A570) for the experimental group and DMSO (control) was measured using a microplate reader (KHB ST-360; Shanghai Kehua Bio-Engineering Co., Ltd.). Finally, actual absorbance was calculated using the following formula: Actual absorbance $=$ absorbance of treated cultures-absorbance of DMSO. To ensure consistency, the experiment was repeated three times in all cases.

Colony formation assay. For each treatment, cells were plated at $1 \times 10^{3}$ cells/well in 6-well plates in triplicate. After the cells were attached, the cells were treated with 0,20 or $50 \mathrm{mM}$ metformin for 14 days and then fixed in $-20^{\circ} \mathrm{C}$ precooled methanol/acetone (1:1) solution for $10 \mathrm{~min}$. After fixation, the cells were stained using crystal violet (Sigma-Aldrich; Merck KGaA; cat. no. C0775) for $1 \mathrm{~min}$ at room temperature. The colonies with $\geq 50$ cells were manually counted under an inverted light microscope (magnification, x400; CX31; Olympus Corporation). The number of colonies for breast cancer cells were calculated as: Colonies/500x100.

Cell cycle analysis. The cells were seeded in 6-well plates $\left(2 \times 10^{5}\right.$ cells/well $)$ overnight and then exposed to 0,20 and $50 \mathrm{mM}$ metformin for another $48 \mathrm{~h}$. Exponentially growing cells were trypsinized and precipitated overnight with $70 \%$ ethanol at $4^{\circ} \mathrm{C}$. Next, the cells were washed, resuspended in fresh PBS containing propidium iodide 
with 0.1\% Triton X-100 (Sigma-Aldrich; Merck KGaA) and RNase A (Beyotime Institute of Biotechnology), and then the reaction was further incubated for $30 \mathrm{~min}$ in the dark at $37^{\circ} \mathrm{C}$. Cell cycle distribution was determined using the BD FACSAria $^{\mathrm{TM}}$ III Cell Sorting system (Becton, Dickinson and Company) and analyzed using the ModFit LT software (version 5.0; Becton, Dickinson and Company).

Xenografts. Subcutaneous xenograft mouse models were used to estimate the antitumor efficacy of metformin. A total of 10 female athymic BALB/c nude mice (4-week-old; average weight, $20 \mathrm{~g}$ ) were kept under pathogen-free conditions. All animals were housed in metabolic cages (dimensions, $500 \times 360 \times 200 \mathrm{~mm}$ ), with 2 or 3 mice per cage. During the experimental procedure, nude mice were kept at a temperature of $23 \pm 2^{\circ} \mathrm{C}$, humidity of $50 \pm 10 \%$ and light-controlled environment (12/12-h light/dark cycle). The mice were free to drink and eat. The litter was changed every other day. After completing the experiment, the mice were sacrificed by cervical dislocation after anesthesia with an intraperitoneal injection of $0.6 \%$ sodium pentobarbital $(40 \mathrm{mg} / \mathrm{kg})$. Death was carefully verified by monitoring cessation of corneal reflex, heartbeat and breathing. $4 \mathrm{~T} 1$ cells $\left(1 \times 10^{6}\right.$ cells/mouse) in PBS were injected subcutaneously into the right upper flank of the mice. When the mean tumor diameter was $\sim 4 \mathrm{~mm}$, the animals were randomly assigned to two groups (control group and metformin treatment group, $\mathrm{n}=5$ in each group). Metformin $(250 \mathrm{mg} / \mathrm{kg}$ ) was injected intraperitoneally once daily. The control group was treated similarly but with sterile saline solution instead of metformin $(0.9 \% \mathrm{NaCl}$ in ultrapure water). Tumor long/short diameter was measured every 2-3 days. All animals were sacrificed after the end of the experiment at day 14 , and the tumors were harvested and weighed. The length of tumor was measured by caliper, and tumor volume $\left(\mathrm{mm}^{3}\right)$ was estimated by the formula $\mathrm{V}=0.52 \mathrm{x}$ length $\mathrm{x}$ width $\mathrm{x}$ depth. Humane endpoint criteria were defined as follows: i) body weight loss persisted beyond $20 \%$ of predose weight; ii) tumor size exceeding $3,000 \mathrm{~mm}^{3}$; and iii) anorexia or loss of mobility. All animal experimental protocols were reviewed and approved by the Animal Ethics Committee of the Second Military Medical University (Shanghai, China).

Western blot analysis. Standard western blotting was performed as previously described (41). In short, whole-cell lysates were prepared from 4T1 and MCF7 cells at 0, 24, 48 and $72 \mathrm{~h}$ after the addition of metformin $(0,20$ and $50 \mathrm{mM})$. Breast cancer cells were lysed using RIPA lysis buffer (Sangon Biotech Co., Ltd.). Total protein concentration was quantified using the BCA method. The protein samples (30 $\mu \mathrm{g} /$ lane) were electrophoresed via $10 \%$ SDS-PAGE and then transferred to a polyvinylidene fluoride membrane (Bio-Rad Laboratories, Inc.). After being blocked with 1\% BSA (Sigma-Aldrich; Merck $\mathrm{KGaA}$ ) for at least $2 \mathrm{~h}$ at room temperature, the membranes were incubated overnight with the aforementioned primary antibodies for $10-12 \mathrm{~h}$ at $4^{\circ} \mathrm{C}$ (p-AMPK $\alpha, \mathrm{AMPK} \alpha$, $\beta$-actin, cyclin D1, p-4E-BP1, 4E-BP1, PGE2 and COX-2; all 1:1,000) and then incubated for $2 \mathrm{~h}$ at room temperature with HRP-conjugated anti-rabbit (1:1,000; cat. no. ab205718; Abcam) and anti-mouse (1:1,000; cat. no. ab205719; Abcam) secondary antibodies. Finally, the membranes were washed three times and immunoreactive proteins were detected using an enhanced chemiluminescence kit (Amersham; Cytiva) and analyzed using Quantity One software version 4.6 (Bio-Rad Laboratories, Inc.).

Hematoxylin and eosin $(H \& E)$ staining and immunohistochemistry (IHC). Tumor and adjacent normal tissues (confirmed as normal by the pathology department) were fixed in $10 \%$ formalin for $24 \mathrm{~h}$ at room temperature, embedded in paraffin and cut into 4- $\mu$ m-thick sections for IHC or $\mathrm{H} \& \mathrm{E}$. IHC and $\mathrm{H} \& \mathrm{E}$ staining were performed using the Histostain ${ }^{\mathrm{TM}}$ kit (Thermo Fisher Scientific, Inc.) following the manufacturer's protocol. Briefly, the tissue slides were deparaffinized in xylene (three washes for $5 \mathrm{~min}$ each) and graded ethanol dilution series $(100,95,70$ and 50\% ethanol, each washed twice for $10 \mathrm{~min}$ each) and washed in deionized water (two washes for 5 min each). The slides were then fixed in 10\% paraformaldehyde for $10 \mathrm{~min}$ at room temperature and subsequently rinsed in PBS. Fixed samples were incubated with $3 \% \mathrm{H}_{2} \mathrm{O}_{2}$ solution at room temperature for $10 \mathrm{~min}$ followed by washing with PBS three times. Antigen retrieval was achieved by boiling slides in $0.01 \mathrm{M}$ citrate buffer, $\mathrm{pH} 6.0$, for $10 \mathrm{~min}$, cooling to room temperature and rinsing three times with PBS. Tissue sections were incubated with serum blocking solution provided in the aforementioned kit for $10 \mathrm{~min}$ at room temperature, followed by incubation with primary antibody against p-AMPK $\alpha$ (1:100), COX-2 (1:100), cyclin D1 (1:100), PCNA (1:100) and p-4E-BP1 (1:200) at room temperature for $1 \mathrm{~h}$. After washing off the primary antibody in PBS, sections were incubated with biotinylated broad-spectrum secondary antibody (Histostain ${ }^{\circledR}$-Plus 3rd Gen IHC Detection kit; Invitrogen; Thermo Fisher Scientific, Inc.; cat. no. 85-903) at room temperature for $10 \mathrm{~min}$. At the end of incubation, the sections were washed again in PBS, and then incubated for a further $10 \mathrm{~min}$ at room temperature in the presence of streptavidin-enzyme conjugate. After washing with PBS, sections were incubated with substrate-chromogen mixture at room temperature for $5 \mathrm{~min}$ and washed with PBS again. Hematoxylin was used to stain slices for $1 \mathrm{~min}$ at room temperature, followed by a rinse with tap water. Sections were finally mounted and dried until observation. Tissue samples were evaluated and blindly scored by two independent investigators using a light microscope (Olympus Corporation). The criteria for scoring were as follows: 0 , absence of positive staining; 1 , weak staining intensity; 2 , moderate staining intensity; and 3 , strong staining intensity. The percentage of positively stained cells was obtained in at least five different visual fields at $\mathrm{x} 400$ magnification for each section, and assigned a value between 0 and $100 \%$. The final score of immunoreactivity was obtained by multiplying the staining intensity score by the percentage of positive tumor cells in each case. The scores ranged from 0 ( $0 \%$ of cells stained) to 3 ( $100 \%$ strong staining).

Reverse transcription-quantitative PCR (RT-qPCR). Total RNA from cells was isolated using TRIzol ${ }^{\circledR}$ reagent (Invitrogen; Thermo Fisher Scientific, Inc.). First, first-strand cDNA was reverse transcribed from $1 \mu \mathrm{g}$ total RNA using M-MLV reverse transcriptase (Invitrogen; Thermo Fisher Scientific, Inc.) at $37^{\circ} \mathrm{C}$ for 10 min according to the manufacturer's instructions of the PrimeScript RT reagent kit 
(Takara Bio, Inc.). qPCR was performed on the 7500HT Fast Real-Time PCR machine (Applied Biosystems; Thermo Fisher Scientific, Inc.) using SYBR-Green Master mix (Takara Bio, Inc.). The thermocycling conditions were as follows: Enzyme activation at $95^{\circ} \mathrm{C}$ for $30 \mathrm{sec} ; 30$ cycles of denaturation and annealing at $95^{\circ} \mathrm{C}$ for $5 \mathrm{sec}$ and $55^{\circ} \mathrm{C}$ for $20 \mathrm{sec}$, respectively; hold at $4^{\circ} \mathrm{C}$. Relative gene expression was determined using the SYBR Green Master Mix (Takara Bio, Inc.). GAPDH was used for internal expression normalization. Relative expression levels were normalized to endogenous controls and were expressed as $2^{-\Delta \Delta C q}$ (42). Each sample was analyzed in triplicates for the target genes and internal control gene. The primers for qPCR were as follows: $C O X-2$ forward, 5'-ATCATTCACCAGGCAAATTGC-3' and reverse, 5'-GGCTTCAGCATAAAGCGTTTG-3'; and GAPDH forward, 5'-TGTTGCCATCAATGACCCCTT-3'; and reverse, 5'-CTCCACGACGTACTCAGCG-3'.

Luciferase reporter assay. Breast cancer cells were seeded in 24-well plates and grown to $70-80 \%$ confluence. The cells were transfected with the human COX-2 promoter fragments (a generous gift from Professor Qi Li, Shuguang Hospital, Shanghai, China) using Lipofectamine 3000 (Invitrogen; Thermo Fisher Scientific, Inc.) at $37^{\circ} \mathrm{C}$ with $5 \% \mathrm{CO}_{2}$ for $6 \mathrm{~h}$, which were inserted into the pGL3 plasmid (Promega Corporation; cat. no. E1761) and monitor plasmid pRL-TK (Promega Corporation; cat. no. E2241). These cells were treated with 0,20 or $50 \mathrm{mM}$ metformin. After $48 \mathrm{~h}$ of treatment, cells were collected, washed and harvested to measure the firefly and Renilla luciferase activities using the Dual-Glo ${ }^{\text {TM }}$ Luciferase reporter assay system (Promega Corporation; cat. no. E2920) according to the manufacturer's instructions. Luciferase activity was normalized to that of the co-transfected pRL-TK plasmid. All experiments were performed at least twice in triplicates.

Statistical analysis. All data were analyzed using either unpaired or paired Student's t-test, Pearson's correlation, one-way ANOVA with Tukey's post-hoc test or $\chi^{2}$ test. Data analysis were applied using SPSS version 22.0 (IBM Corp.) and GraphPad Prism version 6.0 (GraphPad Software, Inc.). For all tests, a two-sided $\mathrm{P}<0.05$ was considered to indicate a statistically significant difference.

\section{Results}

Metformin inhibits proliferation and colony formation in breast cancer cells. To investigate the effects of metformin on cell proliferation, MCF7 and 4T1 cells were treated with various concentrations $(0,20$ and $50 \mathrm{mM})$ of metformin and cell viability was measured at the indicated times (0-144 h). As shown in Fig. 1A and B, metformin led to a decrease in cell proliferation in a dose- and time-dependent manner in the two cell lines tested. At the maximum concentration of the drug $(50 \mathrm{mM})$, the proliferation of the two cell lines was almost completely blocked at $144 \mathrm{~h}$. Furthermore, metformin significantly inhibited the colony forming efficiency of both cell lines in a dose-dependent manner (Fig. 1C-E). At $20 \mathrm{mM}$ concentration, metformin decreased the overall rate of colony formation of MCF7 and 4T1 cells by $>60 \%$ compared with untreated cells, while at $50 \mathrm{mM}$, metformin inhibited colony formation by $100 \%$ compared with untreated cells (Fig. 1C-E). These data indicated that metformin effectively inhibited breast cancer cell proliferation in vitro.

Metformin downregulates cyclin D1 expression and induces $G_{0} / G_{I}$ cell cycle arrest in breast cancer cells. To further study the effect of metformin on cell cycle progression, the percentage of cells in each respective cell cycle phase was detected by flow cytometry. As shown in Fig. $1 F$ and $G$, metformin markedly increased the proportion of cells in $G_{0} / G_{1}$ phase by $>10 \%$ compared with untreated cells, whereas the number of cells in the S phase was markedly decreased, especially in 4T1 cells. Moreover, cyclin D1 protein expression, a key regular of the $G_{1} / S$ transition, was markedly downregulated in a dose-dependent manner in cells treated with metformin compared with in control cells (Fig. 1H). Overall, these results demonstrated that metformin exerted its antitumor activity by inducing cell cycle arrest.

Metformin inhibits the growth of $4 T 1$ cell xenografts in nude mice. To determine the inhibitory effect of metformin on cell proliferation in vivo, nude mice were subcutaneously injected with $4 \mathrm{~T} 1$ cells, and treated daily with metformin $(250 \mathrm{mg} / \mathrm{kg})$ or saline when the diameter of xenograft tumors reached $4 \mathrm{~mm}$. Mice were sacrificed after 2 weeks and tumors were excised. As shown in Fig. 2A-C, the administration of metformin alone significantly decreased the growth of tumor-cell xenografts in vivo. The H\&E-stained slides of paraffin-embedded excised tumors indicated a decrease in tumor cell volume and density in treated mice compared with in untreated mice (Fig. 2D). Furthermore, consistent with the aforementioned results in vitro, a significant decrease in cyclin D1 and PCNA expression was observed in metformin-treated tumors compared with in untreated tumors (Fig. 2D-F). Thus, these results demonstrated that metformin inhibited the growth of breast cancer cell xenografts in nude mice.

Metformin activates $A M P K$ and inhibits $C O X-2$ in vitro and in vivo. The anticancer effects of metformin are mediated via the AMPK signaling pathway (43). Therefore, the present study investigated whether metformin could activate AMPK by measuring the levels of p-AMPK at Thr-172. As expected, treatment of 4T1 and MCF7 cells with metformin significantly increased p-AMPK levels (Fig. 3A) and relative protein levels of p-AMPK/AMPK (Fig. 3B) in a dose-dependent manner. In vivo, significantly increased levels of p-AMPK $\alpha$ were observed in xenograft tumor sections obtained from mice after metformin treatment compared with in those obtained from untreated mice (Fig. 3D). Previously, it has been shown that activation of the AMPK signaling pathway with epigallocatechin-3-gallate (EGCG) abrogates COX-2 expression and PGE2 production in colon cancer cells (44). Thus, the present study studied whether metformin could inhibit COX-2 expression and PGE2 production. The current results revealed that metformin inhibited COX-2 and PGE2 expression in breast cancer cells in a dose- and time-dependent manner (Fig. 3A and C). This was also reflected in the percentage of positively-stained cells in the tissues of mice 

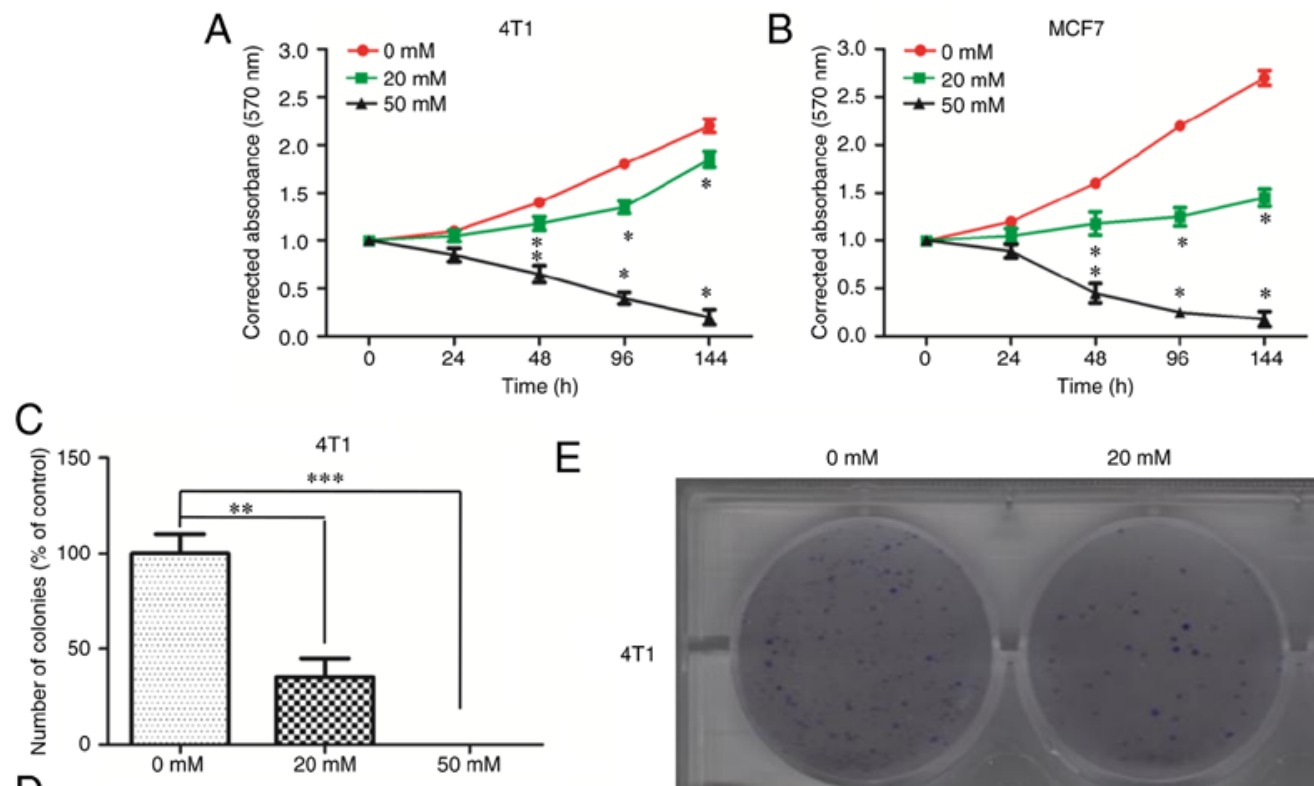

E
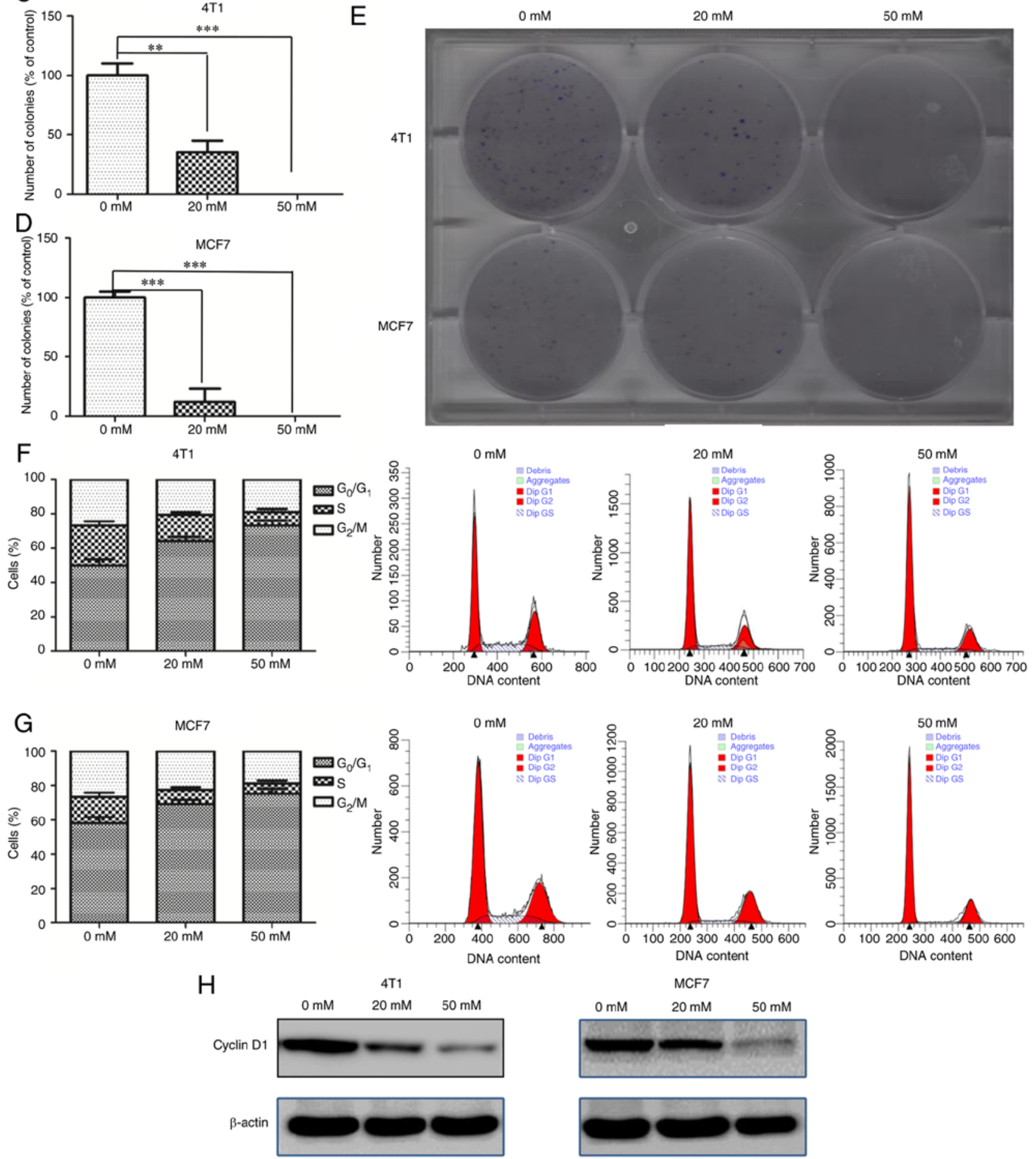

Figure 1. Metformin inhibits proliferation and colony formation, induces $\mathrm{G}_{0} / \mathrm{G}_{1}$ cell cycle arrest and decreases cyclin $\mathrm{D} 1$ expression in breast cancer cells. Cell proliferation in (A) 4T1 and (B) MCF7 treated with metformin $(0,20$ and $50 \mathrm{mM})$ measured using MTT assay. ${ }^{*} \mathrm{P}<0.05$ vs. control group $(0 \mathrm{mM})$. The number of cell colonies ( $>50$ cells) for (C) $4 \mathrm{~T} 1$ and (D) MCF7 cells were calculated as: Colonies $/ 500 x 100{ }^{* *} \mathrm{P}<0.01 ;{ }^{* * * *} \mathrm{P}<0.001$. (E) Representative images of cell colony formation. Cell cycle analysis using flow cytometry in (F) $4 \mathrm{~T} 1$ and (G) MCF7 cells. Proportions of cells in the $\mathrm{G}_{0} / \mathrm{G}_{1}, \mathrm{~S}$ or $\mathrm{G}_{2} / \mathrm{M}$ phases of the cell cycle are indicated. $(\mathrm{H})$ Western blot analysis for cyclin D1 in breast cancer cells treated for $48 \mathrm{~h}$ with metformin $(0,20$ and $50 \mathrm{mM})$. 


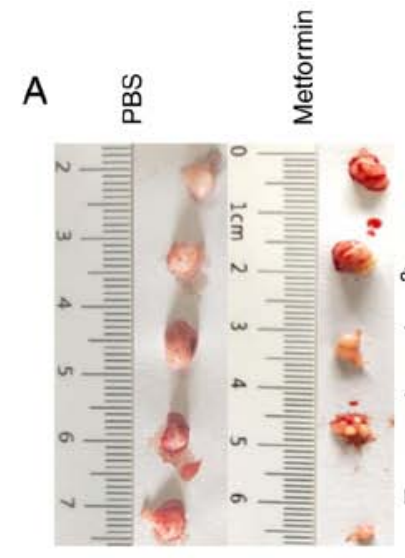

B

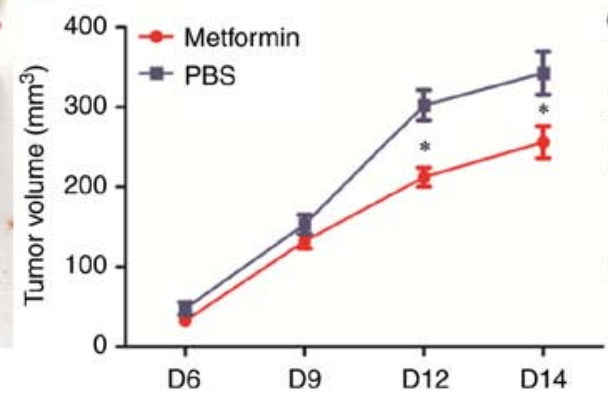

D
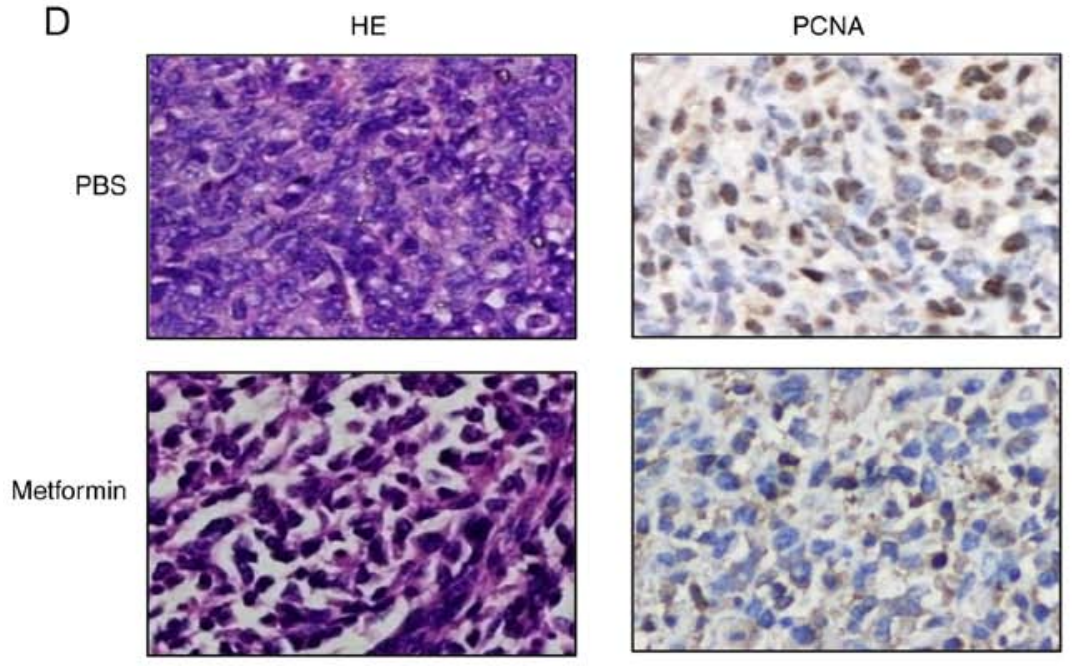

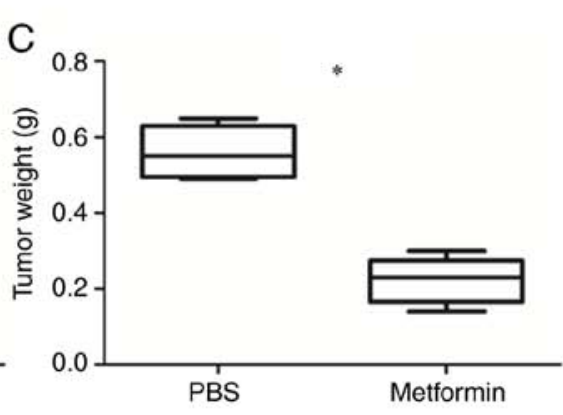

Cyclin D1
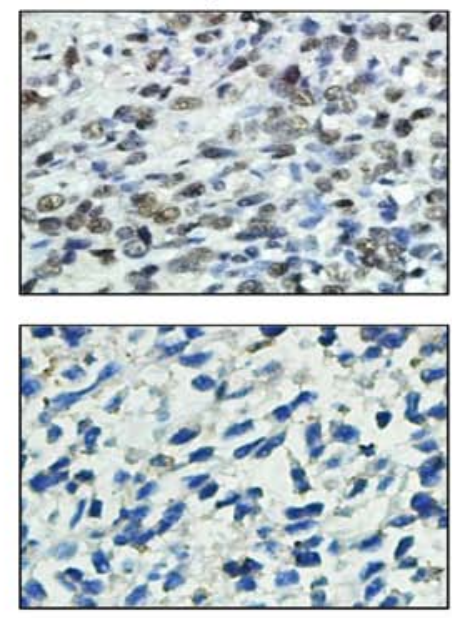
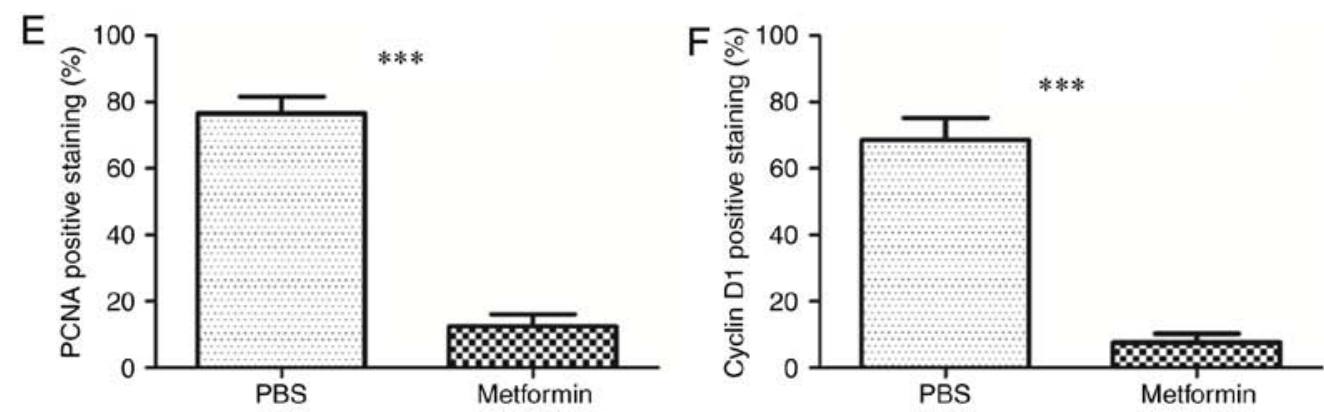

Figure 2. Metformin inhibits breast tumor growth in vivo. (A) Representative images of the excised tumors of untreated and treated groups (n=5 per group). (B) Longitudinal tumor growth curves of $4 \mathrm{~T} 1$ cell xenografts after metformin treatment. ${ }^{*} \mathrm{P}<0.05$ vs. PBS. (C) Tumor weight of $4 \mathrm{~T} 1$ cell xenografts. ${ }^{*} \mathrm{P}<0.05$. (D) Representative images of immunohistochemical analysis of 4T1 xenografts demonstrating staining of HE, PCNA and cyclin D1 in tumor sections from untreated and metformin-treated groups (magnification, x200). Quantification of differences of (E) PCNA and (F) cyclin D1 expression in metformin-treated and untreated groups ${ }^{* * *} \mathrm{P}<0.001$. HE, hematoxylin and eosin; PCNA, proliferating cell nuclear antigen.

treated with metformin (Fig. 3D). In summary, these findings strongly suggested that metformin may be a potent inhibitor of the COX-2 signaling pathway and may modulate cell cycle progression to restrain tumor growth.

Metformin inhibits the transcription of $C O X-2$. To determine whether metformin transcriptionally regulates COX-2, a pGL3-COX-2 plasmid containing a 2,000-bp region upstream of the human COX-2 promoter was used. The dual luciferase assay indicated that compared with no treatment, the relative COX-2 promoter activity was significantly decreased upon treatment of 4T1 and MCF7 cells with metformin (Fig. 4A and B). Moreover, the mRNA expression levels of COX-2 were significantly decreased upon treatment of both cells with metformin (Fig. 4C and D). These data indicated that metformin inhibited COX-2 transcription.

Expression profiles of $C O X-2$ and $p-A M P K \alpha$ in patients with breast cancer. Next, $\mathrm{p}-\mathrm{AMPK} \alpha$ and COX-2 protein expression was measured in the tissues of 63 cases with invasive breast cancer. p-AMPK $\alpha$ and COX-2 were primarily expressed in 
A A
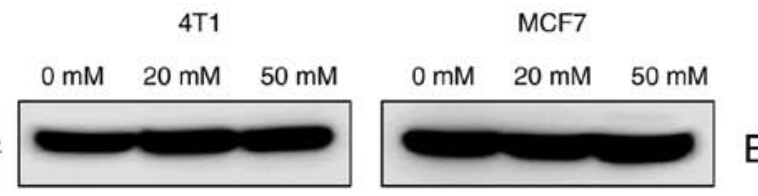

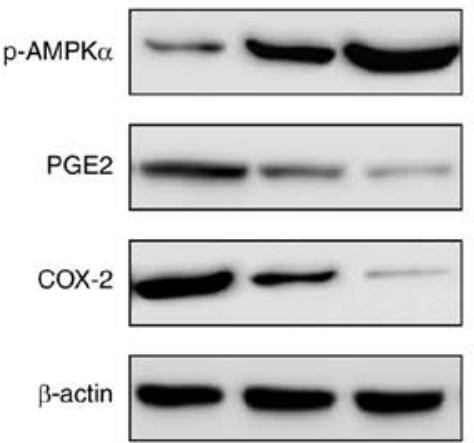

C
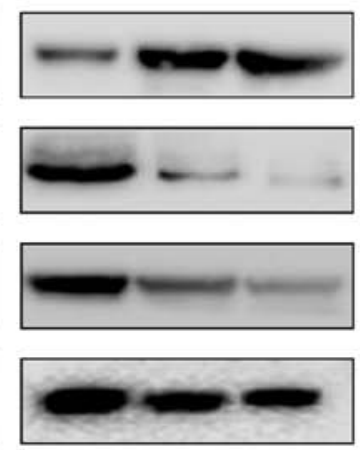

4T1
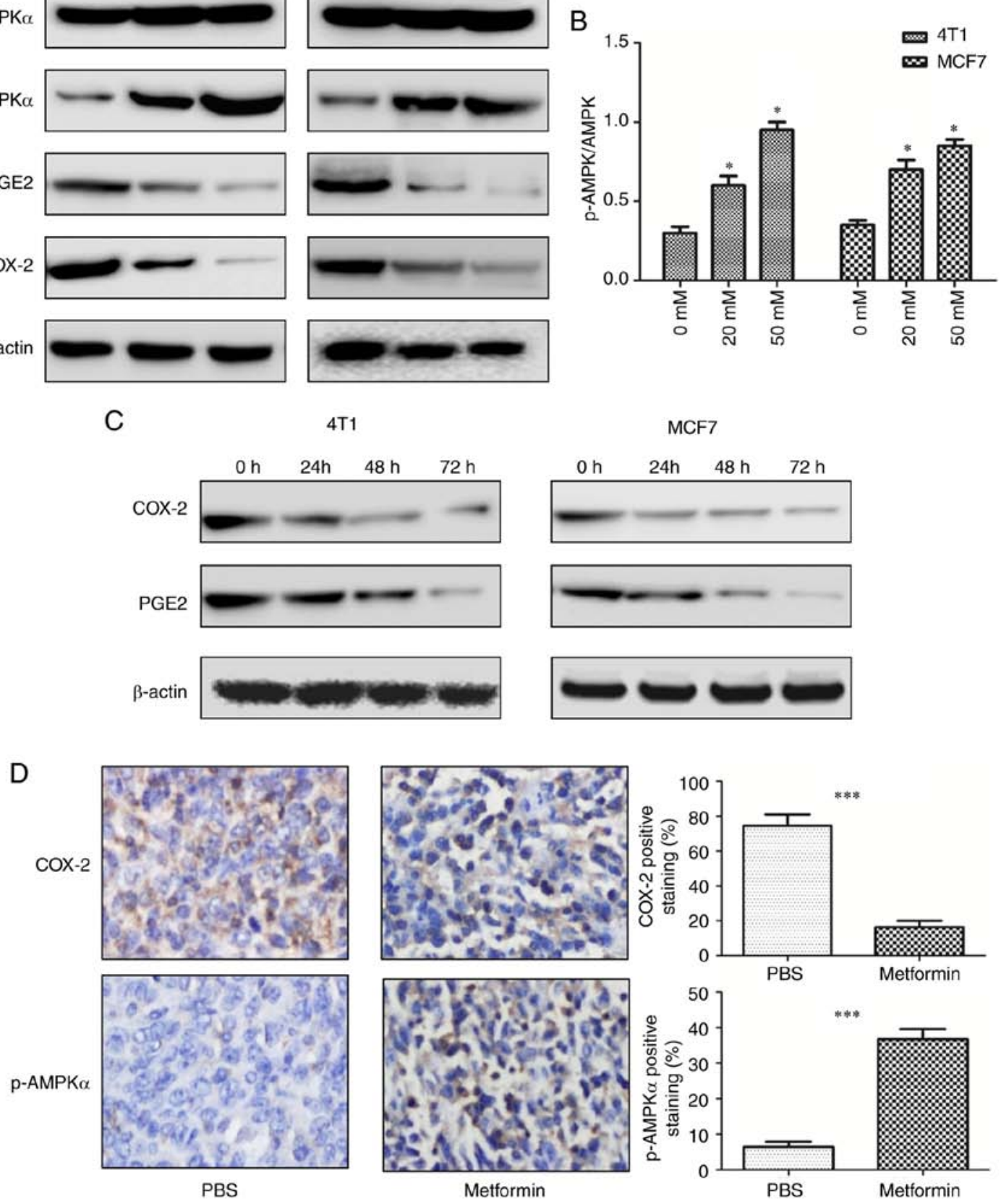

MCF7

Figure 3. Metformin treatment activates AMPK $\alpha$ and inhibits COX-2 expression in breast cancer cells. (A) Western blot analysis of AMPK $\alpha$, p-AMPK $\alpha$, PGE2 and COX-2 in cells treated with or without metformin for $48 \mathrm{~h}$. (B) Quantitative analysis of the proportion of p-AMPK/AMPK. ${ }^{*} \mathrm{P}<0.05$ vs. control group $(0 \mathrm{mM})$. (C) Western blot analysis for COX-2 and PGE2 in cells treated with or without metformin. (D) Representative images and quantification of immunohistochemical analysis of COX-2 and p-AMPK $\alpha$ levels in tumor sections obtained from untreated and metformin-treated mice (magnification, $\mathrm{x} 200$ ). ${ }^{* * *} \mathrm{P}<0.001$. AMPK, AMP kinase; COX-2, cyclooxygenase-2; PGE2, prostaglandin E2; p, phosphorylated.

the cytoplasm of cells obtained from normal breast and tumor tissues (Fig. 5). Furthermore, downregulation of p-AMPK $\alpha$ and upregulation of COX-2 expression was observed in the tumor tissues compared with in adjacent non-cancerous tissues (Fig. 5A-F). The mean expression values of COX-2 in tumor tissues were significantly increased compared with in normal tissues $(1.36 \pm 0.97$ vs. $0.70 \pm 0.61$, respectively; Fig. $5 \mathrm{E})$. By contrast, the mean values of $\mathrm{p}$-AMPK $\alpha$ in tumors $(0.82 \pm 0.84)$ were significantly lower than in normal tissues $(2.37 \pm 0.31)$ (Fig. 5F).
The association of clinicopathological variables with COX-2 and $\mathrm{p}$-AMPK $\alpha$ expression is summarized in Table I. Increased levels of COX-2 were significantly associated with lymphatic metastasis and TNM stage in patients with breast cancer. COX-2 expression was more common in breast tumors with lymphatic metastasis $(81.0 \%)$ than in those without lymphatic metastasis (42.9\%) ( $\mathrm{P}=0.004$; Table I). Additionally, COX-2 expression was more common in patients with stage III/IV $(90.0 \%)$ than in those with stage I/II disease $(49.1 \%)(\mathrm{P}=0.017$; Table I). Moreover, COX-2 expression was significantly lower 
A

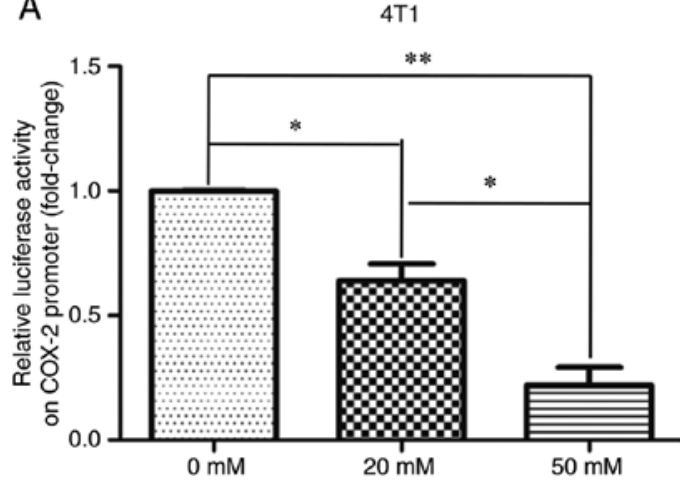

C

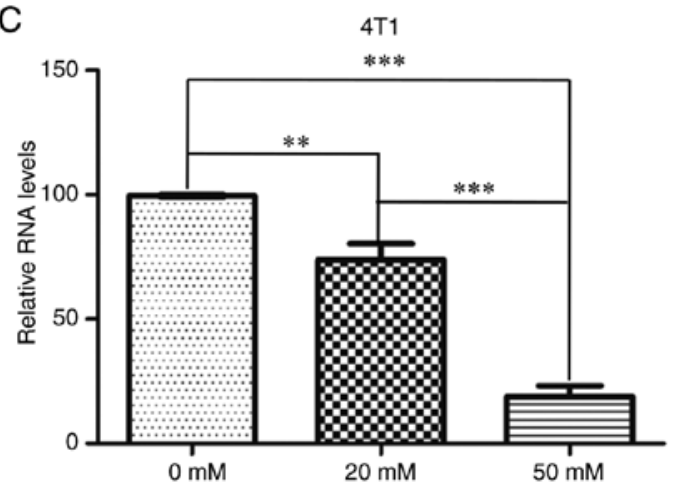

B

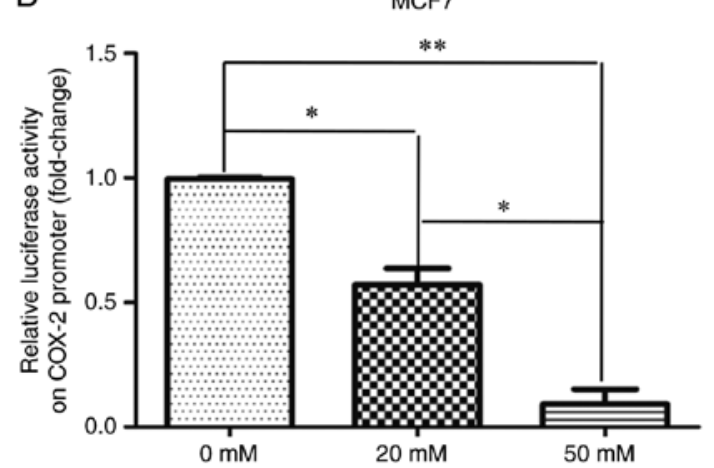

D

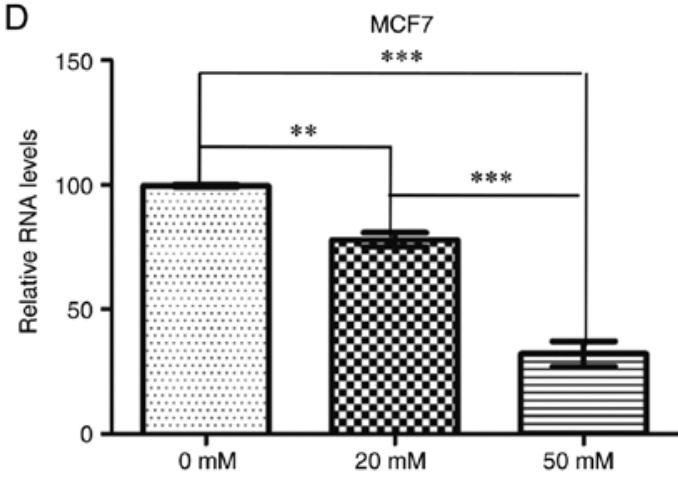

Figure 4. Metformin treatment inactivates COX-2 transcription. Relative luciferase activity in (A) 4T1 and (B) MCF7 cells co-transfected with COX-2 promoter-luciferase construct and Renilla luciferase, and treated with metformin ( 0,20 and 50 mM). Reverse transcription-quantitative PCR analysis of COX-2 expression in (C) 4T1 and (D) MCF7 cells treated with metformin (0, 20 and $50 \mathrm{mM})$ for 48 h. ${ }^{*} \mathrm{P}<0.05,{ }^{* *} \mathrm{P}<0.01$ and ${ }^{* * *} \mathrm{P}<0.001$. COX-2. cyclooxygenase-2.

in stage I/II tumors $(1.40 \pm 0.97)$ compared with in stage III/IV

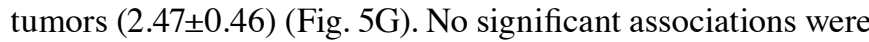
identified between COX-2 expression and other clinicopathological factors, such as age, T stage, and ER, PR, HER2 and p53 status ( $P>0.05$; Table I). Compared with in non-cancerous ductal tissues, $\mathrm{p}$-AMPK $\alpha$ expression was significantly lower in primary tumors (Fig. 5F), but there was no significant association between $\mathrm{p}$-AMPK $\alpha$ and any clinicopathological variable (Table I). However, p-AMPK $\alpha$ expression was significantly higher in stage I/II tumors $(0.84 \pm 0.81)$ compared with in stage III/IV tumors $(0.45 \pm 0.71)$ (Fig. $5 \mathrm{H})$.

Metformin inhibits phosphorylation of $4 E-B P 1$ in vitro and in vivo. The activation of AMPK inhibits the mTOR signaling pathway and decreases phosphorylation of S6 kinase (S6K) in breast cancer (45). Thus, the specific effects of metformin on 4E-BP1 (Thr-37/46), another downstream target of mTOR, were examined in the present study. As shown in Fig. 6A-D, the phosphorylation levels of 4E-BP1 and relative protein levels of $\mathrm{p}$-AMPK/AMPK decreased in a dose- and time-dependent manner following metformin treatment. The p-4E-BP1 levels were significantly decreased in excised mouse tumors after treatment with metformin (Fig. 6E). The current results are consistent with a previous study that has demonstrated that metformin inhibits tumor growth mainly via the AMPK/mTOR signaling pathway (46).

Subsequently, the expression profile of $\mathrm{p}-4 \mathrm{E}-\mathrm{BP} 1$ in breast cancer specimens and the correlation between the levels of p-4E-BP1 and COX-2 were evaluated. p-4E-BP1 staining was preferentially localized to the cytoplasm and was markedly increased in tumor tissues compared with in adjacent non-cancerous breast epithelium (Fig. 6F). Of the 63 tumors, 37 (58.7\%) exhibited high p-4E-BP1 levels, which were significantly associated with lymphatic metastasis and TNM stage (Table I). Co-expression of COX-2 and p-4E-BP1 was observed in $32(50.8 \%)$ tumors, while $23(36.5 \%)$ showed no expression of either COX-2 or p-4E-BP1 $\left(\chi^{2}=34.738\right.$; $\mathrm{P}<0.001$; Fig. 6G). Pearson correlation analysis revealed that COX-2 expression was positively correlated with $\mathrm{p}-4 \mathrm{E}-\mathrm{BP} 1$ expression among the 63 breast tumors $(\mathrm{r}=0.743 ; \mathrm{P}<0.001$; Fig. 6H). Furthermore, COX-2 expression co-localized with p-4E BP1 levels in the same specimens (Fig. 6F). Overall, the current data suggested that activation of AMPK by metformin may lead to inhibition of the mTOR signaling pathway and COX-2 expression, resulting in decreased cell proliferation and tumor growth (Fig. 6I).

\section{Discussion}

The present study aimed to explore a novel anticancer mechanism of the anti-diabetic drug metformin. Metformin is known to exert its antitumor effects by activating AMPK and inhibiting mTOR-mediated phosphorylation of S6K1 and 4E-BP1 in the AMPK/mTOR signaling pathway (47). The current study described a novel role of metformin by demonstrating that metformin significantly suppressed cell proliferation in vitro and decreased tumor growth in vivo by targeting the COX-2 and AMPK/mTOR signaling pathways. Treatment with metformin alone significantly decreased the expression levels of COX-2 and p-4E-BP1 in breast cancer 

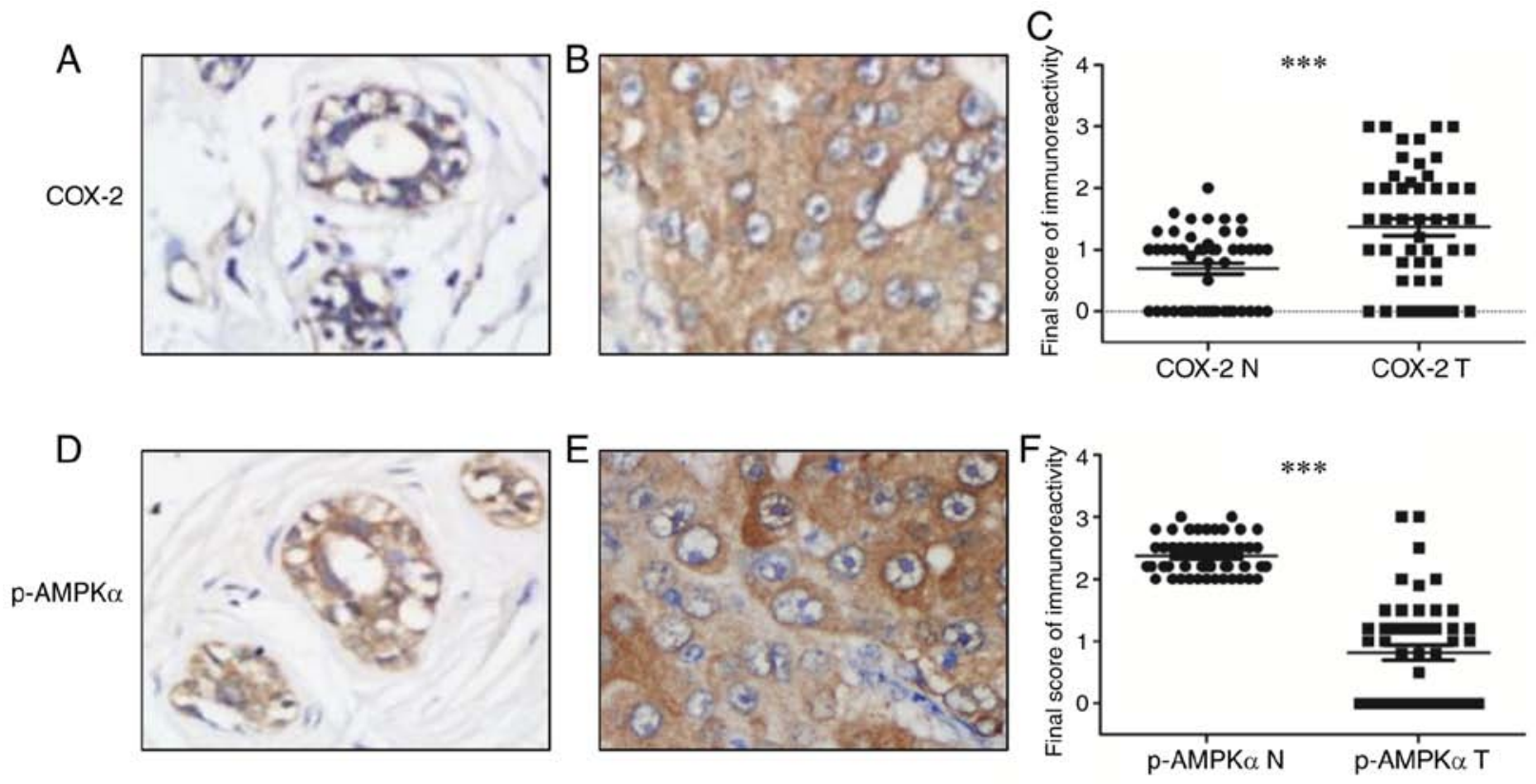

G

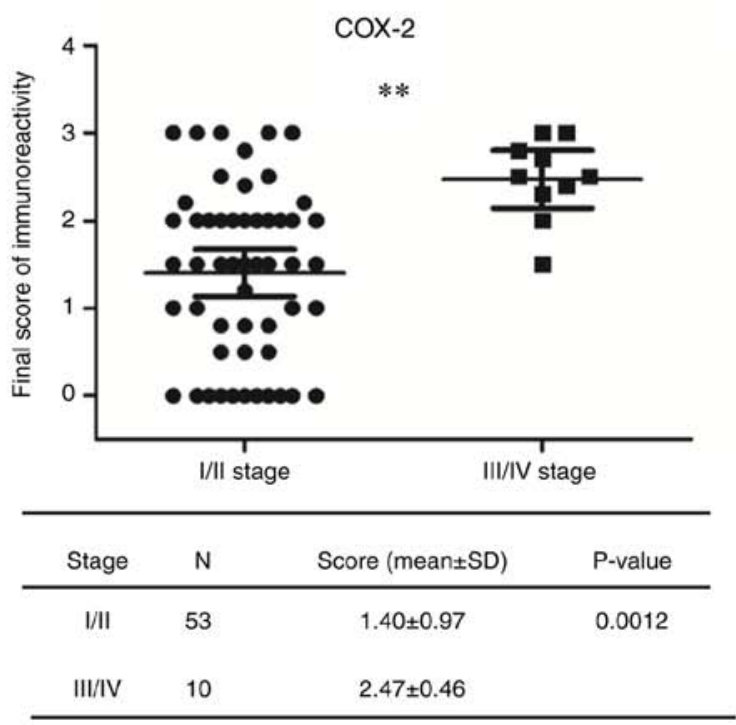

$\mathrm{H}$

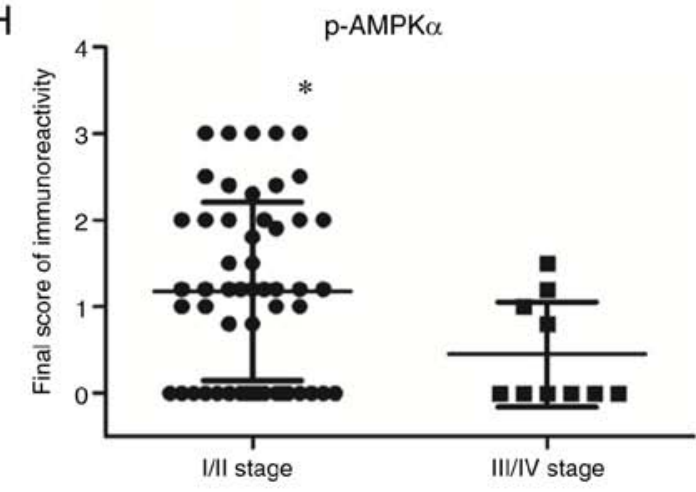

\begin{tabular}{cccc}
\hline Stage & $N$ & Score $($ mean \pm SD) & P-value \\
\hline I/II & 53 & $0.84 \pm 0.81$ & 0.035 \\
III/IV & 10 & $0.45 \pm 0.71$ & \\
\hline
\end{tabular}

Figure 5. Expression profiles of COX-2 and p-AMPK $\alpha$ in breast cancer tissues and non-cancerous ductal epithelium. Representative staining of COX-2 in (A) $\mathrm{N}$ epithelium and (B) $\mathrm{T}$ specimens. (C) Graphical representation of the differences of COX-2 staining in $\mathrm{N}$ and $\mathrm{T}$ tissues. Representative staining of p-AMPK $\alpha$ in (D) N epithelium and (E) T specimens (magnification, x400). (F) Graphical representation of the differences of p-AMPK $\alpha$ staining in $\mathrm{N}$ and $\mathrm{T}$ tissues. Graphical representation of the differences of $(\mathrm{G}) \mathrm{COX}-2$ and $(\mathrm{H}) \mathrm{p}-\mathrm{AMPK} \alpha$ staining between stage $\mathrm{I} / \mathrm{II}$ and stage III/IV. ${ }^{*} \mathrm{P}<0.05$; $^{* *} \mathrm{P}<0.01$; ${ }^{* * * *} \mathrm{P}<0.001$. N, non-neoplastic; T, tumor; p-AMPK, phosphorylated AMP kinase; COX-2, cyclooxygenase-2.

cells. Furthermore, COX-2 and p-4E-BP1 were frequently upregulated and strongly associated with nodal metastasis and advanced disease stage, implicating their dual-role as predictive biomarkers and therapeutic targets in breast cancer.

Clinical and epidemiological studies have demonstrated that compared with individuals without diabetes, the relative risk of progression to breast cancer is increased in patients with type $2 \mathrm{DM}$, and treatment with metformin decreases the relative risk for breast cancer and cancer-associated mortality in diabetic patients (48-50). Pre-clinical studies have indicated that the majority of breast cancer cell lines show sensitivity to metformin treatment $(17,20)$. The present data further confirmed that metformin was able to decrease cell viability in a dose- and time-dependent manner, and inhibited the rate of colony formation in breast cancer cells.
The highest concentration of metformin $(50 \mathrm{mM})$ completely blocked the proliferation rate of breast cancer cells. These anticancer effects of metformin, as evidenced by the increased proportion of cells in $\mathrm{G}_{0} / \mathrm{G}_{1}$ phase and decreased cyclin D1 expression, were associated with cell cycle arrest. Moreover, tumors excised from metformin-treated mice exhibited significantly slower growth and lower tumor volume than those from mice not treated with metformin. Moreover, metformin treatment altered the morphology of cancer cells, as demonstrated by significantly smaller cell types and larger intervals between cells in the xenograft tissues of metformin-treated mice than those in control mice. These changes may be due to a metabolic response to metformin toxicity. Further immunohistochemical analysis confirmed the low proliferation index (as indicated by PCNA) and low 
Table I. Association between COX-2, p-AMPK $\alpha$ and p-4E-BP1 expression and clinicopathologic features in patients with breast cancer $(n=63)$.

\begin{tabular}{|c|c|c|c|c|c|c|c|}
\hline Variables & $\mathrm{N}$ & COX-2,n (\%) & P-value & $\mathrm{p}-\mathrm{AMPK} \alpha, \mathrm{n}(\%)$ & P-value & $\mathrm{p}-4 \mathrm{E}-\mathrm{BP} 1, \mathrm{n}(\%)$ & P-value \\
\hline \multicolumn{8}{|l|}{ Age, years } \\
\hline$<50$ & 29 & $16(55.2)$ & \multirow[t]{2}{*}{0.955} & $15(51.7)$ & \multirow[t]{2}{*}{0.923} & $16(55.2)$ & \multirow[t]{2}{*}{0.596} \\
\hline$\geq 50$ & 34 & $19(55.9)$ & & $18(52.9)$ & & $21(61.8)$ & \\
\hline \multicolumn{8}{|l|}{$\mathrm{pT}$} \\
\hline $\mathrm{pT} 1 / 2$ & 51 & $28(54.9)$ & \multirow[t]{2}{*}{0.830} & $27(52.9)$ & \multirow[t]{2}{*}{0.854} & $31(60.9)$ & \multirow[t]{2}{*}{0.495} \\
\hline $\mathrm{pT} 3 / 4$ & 12 & $7(58.3)$ & & $6(50.0)$ & & $6(50.0)$ & \\
\hline \multicolumn{8}{|l|}{$\mathrm{pN}$} \\
\hline No & 42 & $18(42.9)$ & \multirow[t]{2}{*}{0.004} & $23(45.1)$ & \multirow[t]{2}{*}{0.593} & $20(47.6)$ & \multirow[t]{2}{*}{0.011} \\
\hline Yes & 21 & $17(81.0)$ & & $10(47.6)$ & & $17(81.0)$ & \\
\hline \multicolumn{8}{|c|}{ TNM stage } \\
\hline $\mathrm{I} / \mathrm{II}$ & 53 & $26(49.1)$ & \multirow[t]{2}{*}{0.017} & $30(56.6)$ & \multirow[t]{2}{*}{0.122} & $28(52.8)$ & \multirow[t]{2}{*}{0.029} \\
\hline III/IV & 10 & $9(90.0)$ & & $3(30.0)$ & & $9(90.0)$ & \\
\hline \multicolumn{8}{|l|}{ ER } \\
\hline+ & 34 & $16(47.1)$ & \multirow[t]{2}{*}{0.955} & $20(58.8)$ & \multirow[t]{2}{*}{0.268} & $16(47.1)$ & \multirow[t]{2}{*}{0.596} \\
\hline- & 29 & $19(65.5)$ & & $13(44.8)$ & & $21(72.4)$ & \\
\hline \multicolumn{8}{|l|}{ PR } \\
\hline+ & 32 & $20(62.5)$ & \multirow[t]{2}{*}{0.260} & $18(56.3)$ & \multirow[t]{2}{*}{0.532} & $19(59.4)$ & \multirow[t]{2}{*}{0.685} \\
\hline- & 31 & $15(48.4)$ & & $15(48.4)$ & & $18(58.1)$ & \\
\hline \multicolumn{8}{|l|}{ Her2 } \\
\hline+ & 20 & $14(70.0)$ & \multirow[t]{2}{*}{0.116} & $10(50.0)$ & \multirow[t]{2}{*}{0.796} & $15(75.0)$ & \multirow[t]{2}{*}{0.074} \\
\hline- & 43 & $21(48.8)$ & & $23(53.5)$ & & $22(51.2)$ & \\
\hline \multicolumn{8}{|l|}{ p53 } \\
\hline+ & 26 & $18(69.2)$ & \multirow[t]{3}{*}{0.057} & $15(57.7)$ & \multirow[t]{3}{*}{0.479} & $19(73.1)$ & \multirow[t]{3}{*}{0.156} \\
\hline- & 37 & $17(45.9)$ & & 18 (48.6) & & 18 (48.6) & \\
\hline Total & 63 & $35(55.6)$ & & $33(52.4)$ & & $37(58.7)$ & \\
\hline
\end{tabular}

pT, pathological assessment of primary tumor; pN, pathological assessment of regional lymph node metastasis; ER, estrogen receptor; PR, progesterone receptor; COX-2, cyclooxyeganse-2; p, phosphorylated; AMPK, AMP kinase; 4E-BP1, eukaryotic translation initiation factor 4E-binding protein 1 .

levels of cyclin D1 in the metformin-treated mice compared with in control mice $(16,17)$.

Furthermore, consistent with previous studies (51-53), the present study demonstrated that metformin alone was sufficient to activate AMPK and inhibit p-4E-BP1 and cyclin D1. Metformin decreases PGE2 synthesis by activating AMPK (54), and COX-2 is the key enzyme in PGE2 synthesis (55). Therefore, it was speculated that metformin may serve an anticancer role through the AMPK-mediated COX-2 signaling pathway. To the best of our knowledge, the present study was the first to demonstrate that treatment with metformin alone significantly decreased COX-2 protein expression in a dose- and time-dependent manner in vitro and in vivo. COX-2 is undetectable in most normal tissues and accumulates in activated macrophages and other cells at sites of inflammation (56). A previous study has indicated that COX-2 expression is upregulated in various types of cancer, including gastric, colorectal and lung cancer, and serves a crucial role in tumorigenesis (57). AMPK activation by selenium and EGCG abrogate COX-2 expression in colon cancer cells (44). Similar results were observed in the present study in breast cancer cells upon treatment with another AMPK activator, metformin. The increase in metformin concentrations significantly increased AMPK activity and decreased COX-2 expression. Moreover, continued use of metformin resulted in gradual reduction in COX-2 expression, including at the mRNA level. Additionally, the inhibition of the activity of the pGL3-COX-2-promoter suggested that AMPK activation abolished the transactivation of COX-2. Overall, the current results suggested that metformin regulated COX-2 production at both the transcriptional and post-transcriptional levels, and identified a potential association between AMPK activation by metformin and inhibition of inflammatory events.

AMPK and COX-2 expression is well-studied in human solid cancer tissues, such as gastric, colorectal and ovarian cancer (58-61). p-AMPK expression is decreased in $~ 90 \%$ of patients with breast cancer and is significantly associated with higher histological grade and axillary node metastasis (62). In accordance with the aforementioned studies, the present study 
A
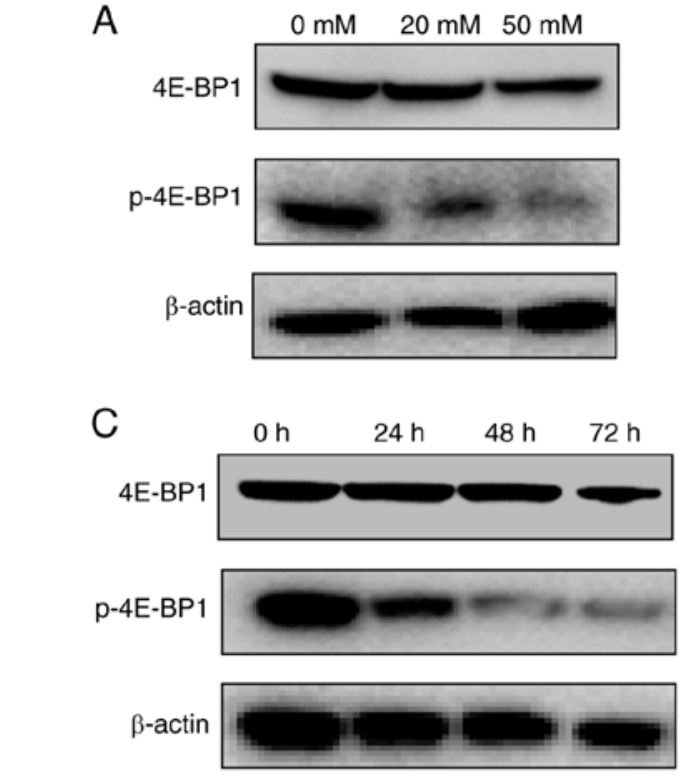

E
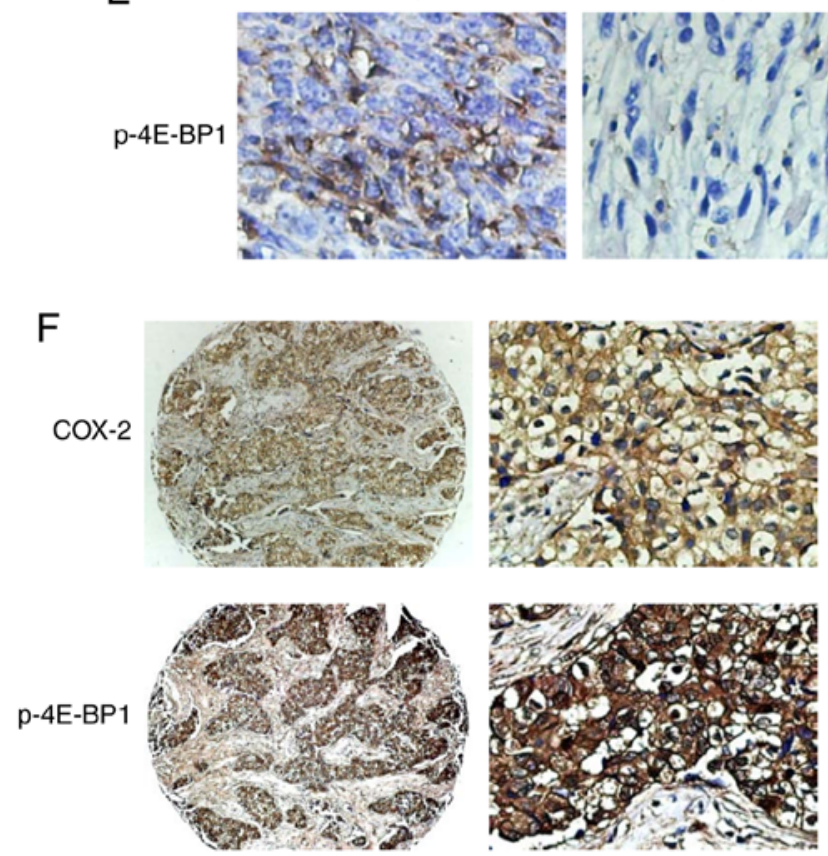

G

\begin{tabular}{cccccc}
\hline \multirow{5}{*}{ COX-2 } & \multicolumn{2}{c}{ p-4E-BP1 } & & & \\
& Positive & Negative & $N$ & P-value & $\chi^{2}$ \\
\hline Positive & 32 & 3 & 35 & $P<0.001$ & 34.738 \\
Negative & 5 & 23 & 28 & & \\
$\mathrm{~N}$ & 37 & 26 & 63 & & \\
\hline
\end{tabular}

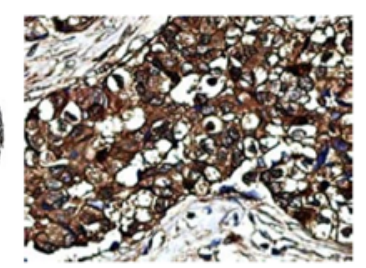

$\mathrm{H}$
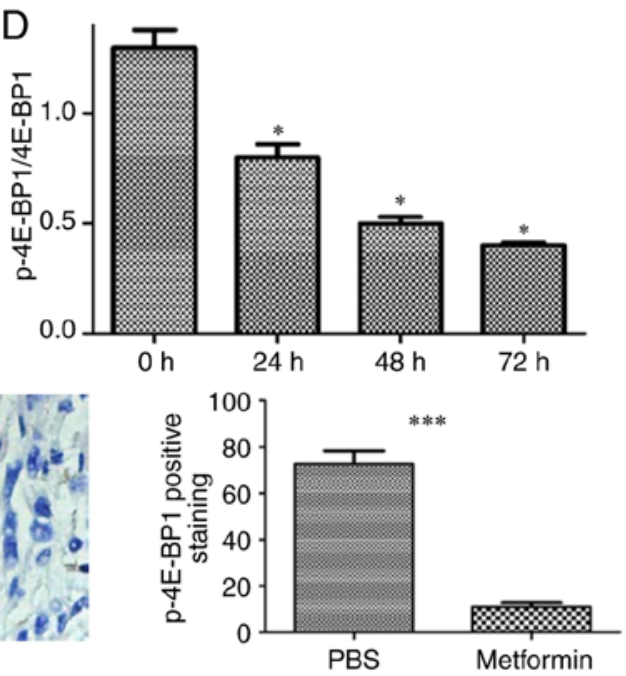

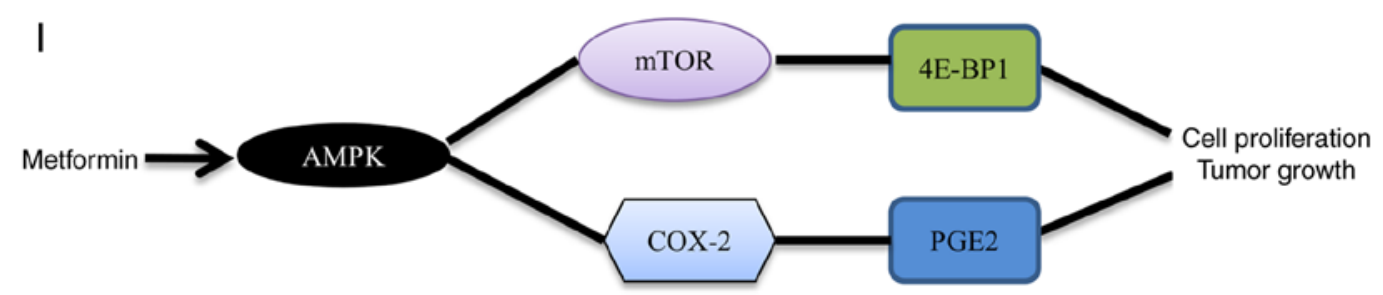

Figure 6. Metformin treatment inhibits phosphorylation of 4E-BP1. (A) Western blot analysis of 4E-BP1 and p-4E-BP1 in 4T1 cells treated with metformin $(0,20$ and $50 \mathrm{mM})$ for $48 \mathrm{~h}$ and $(\mathrm{B})$ quantification of p-4E-BP1/4E-BP1 ratio. (C) Western blot analysis of 4E-BP1 and p-4E-BP1 in 4T1 cells treated with metformin $(20 \mathrm{mM})$ for the indicated time periods and (D) quantification of $\mathrm{p}-4 \mathrm{E}-\mathrm{BP} 1 / 4 \mathrm{E}-\mathrm{BP} 1 \mathrm{ratio}$. $\mathrm{P}<0.05$ vs. control group. (E) Representative images (magnification, $\mathrm{x} 400$ ) and quantification of immunostaining for $\mathrm{p}-4 \mathrm{E}-\mathrm{BP} 1$ in tumor sections from metformin-treated and control mice. ${ }^{* * *} \mathrm{P}<0.001$. (F) Representative staining of COX-2 and p-4E-BP1 in cancer tissues from the same patient (left, x10; right, x400). (G) Association between COX-2 and p-4E-BP1 staining and $(\mathrm{H})$ correlation between COX-2 and p-4E-BP1 expression. (I) Diagrammatic sketch showing that activation of AMPK by metformin leads to inhibition of the mTOR signaling pathway and COX-2 expression, which results in decreased cell proliferation and tumor growth. COX-2, cyclooxyeganse-2; p, phosphorylated; AMPK, AMP kinase; 4E-BP1, eukaryotic translation initiation factor 4E-binding protein 1; PGE2, prostaglandin E2.

demonstrated that p-AMPK $\alpha$ expression was strong in normal breast epithelium and weak in primary breast cancer tissues. The levels of $\mathrm{p}$-AMPK $\alpha$ decreased with disease progression, although no significant association was observed with clinicopathological factors due to the relatively small cohort. Given the association between AMPK and COX-2, it is plausible that 
decreased p-AMPK $\alpha$ levels may be associated with increased COX-2 expression. The current data indicated that COX-2 expression was increased in primary breast cancer specimens compared with in normal breast epithelium, consistent with previous studies $(24,25)$. Additionally, COX-2 positivity was significantly associated with high histological grade and lymph node metastasis. Enhanced COX-2 expression was frequently associated with decreased levels of p-AMPK $\alpha$, although this association was not significant due to the relatively small number of cases in the present study. These data further suggest the importance of the AMPK/COX-2 axis in breast cancer development and progression.

Furthermore, a previous study has revealed that metformin exerts anticancer effects by activating AMPK, which results in inhibition of mTOR kinase and decreased S6K1 activity (63). Consistent with a previous study (18), the present study indicated that metformin also suppressed another mTOR downstream effector, 4E-BP1, thus making it a particularly attractive molecule for investigation in breast cancer. The current data offer a novel mechanistic insight into the potential use of metformin for treatment of breast cancer. Previous studies have demonstrated that p-4E-BP1 levels are associated with malignant progression and adverse prognosis in breast cancer (64-66). The current data revealed that p-4E-BP1 levels were significantly elevated in the majority of breast cancer cases, and p-4E-BP1 positivity was common in cases with nodal metastasis and advanced disease stage. The AMPK/mTOR axis is a well-known effective therapeutic target in metabolic syndromes and cancer, while COX-2 is an established therapeutic target in inflammatory diseases and cancer (67-70). Therefore, cross-talk between the AMPK/mTOR and COX-2 signaling pathways can be expected in cancer pathophysiology. The present results indicated that AMPK activation by metformin decreased both p-4E-BP1 and COX-2 expression in breast cancer cells, which supports the hypothesis that the two pathways are connected. Moreover, immunostaining revealed a close correlation between the levels of these proteins. Thus, p-4E-BP1 and COX-2 may have potential roles as predictive markers and therapeutic targets in breast cancer.

To the best of our knowledge, the present study was the first to demonstrate that metformin activated AMPK and suppressed COX-2 expression to inhibit breast cancer cell proliferation. The current findings are supported by clinical research published by Jiralerspong et al (71), who reported a 3-fold greater complete pathologic response in diabetic patients with breast tumors receiving metformin and neoadjuvant chemotherapy than in those with breast tumors not receiving metformin. Therefore, metformin co-treatment with conventional therapy may serve as a successful therapeutic strategy in the prevention of cancer recurrence and improvement of long-term survival.

In conclusion, the present study revealed the novel finding that metformin activated AMPK, which suppressed the production of COX-2 and abrogated breast cancer cell proliferation. Thus, metformin may serve as a potential therapeutic drug for the treatment of patients with breast cancer, and further studies should be performed to investigate how it may be used in cancer therapy alone or in combination with other antitumor drugs.

\section{Acknowledgements}

The authors would like to thank Professor Yin Chen (Changhai Hospital, Shanghai, China) for data processing and helpful discussions.

\section{Funding}

The present study was partly sponsored by the Guiding Program of Fujian (grant no. 2016Y9064) and the Technological Innovation Foundation of Fujian (grant no. 2015J01408).

\section{Availability of data and materials}

The datasets used and/or analyzed during the current study are available from the corresponding author on reasonable request.

\section{Authors' contributions}

BS and WF conceived and designed the study. BS, $\mathrm{XH}, \mathrm{HH}$ and WF performed the experiments and prepared the manuscript, as well as assessed and confirmed the authenticity of all the raw data. All authors read and approved the final manuscript.

\section{Ethics approval and consent to participate}

The study was performed according to the ethical guidelines of the Declaration of Helsinki and was approved by the Institutional Review Boards of the Kunshan First People's Hospital affiliated with Jiangsu University and the First Affiliated Hospital affiliated with the Second Military Medical University (Changhai Hospital, Shanghai, China) (approval no. CHEC2014-098). Written informed consent for the use of all the clinical specimens was obtained from all patients. All animal experimental protocols were reviewed and approved by the Animal Ethics Committee of the Second Military Medical University (Shanghai, China).

\section{Patient consent for publication}

Not applicable.

\section{Competing interests}

The authors declare that they have no competing interests.

\section{References}

1. Bray F, Ferlay J, Soerjomataram I, Siegel RL, Torre LA and Jemal A: Global cancer statistics 2018: GLOBOCAN estimates of incidence and mortality worldwide for 36 cancers in 185 countries. CA Cancer J Clin 68: 394-424, 2018.

2. American Cancer Society: Breast Cancer Facts and Figures, 2007-2008, May 2009, https://www.cancer.org/content/dam/ cancer-org/research/cancer-facts-and-statistics/breast-cancerfacts-and-figures/breast-cancer-facts-and-figures-2007-2008. pdf. Accessed May 21, 2021.

3. Jemal A, Bray F, Center MM, Ferlay J, Ward E and Forman D: Global cancer statistics. CA Cancer J Clin 61: 69-90, 2011.

4. Miller ME, Muhsen S, Olcese C, Patil S, Morrow M and Van Zee KJ: Contralateral breast cancer risk in women with ductal carcinoma in situ: Is it high enough to justify bilateral mastectomy. Ann Surg Oncol 24: 2889-2897, 2017. 
5. Gandini S, Guerrieri-Gonzaga A, Puntoni $\mathrm{M}$ and Decensi A: Metformin and breast cancer risk. J Clin Oncol 31: 973-974, 2013.

6. Ahmadieh $\mathrm{H}$ and Azar ST: Type 2 diabetes mellitus, oral diabetic medications, insulin therapy, and overall breast cancer risk. ISRN Endocrinol 2013: 181240, 2013.

7. Brower V: Illuminating the diabetes-cancer link. J Natl Cancer Inst 104: 1048-1050, 2012.

8. Suh S and Kim KW: Diabetes and cancer: Is diabetes causally related to cancer. Diabetes Metab J 35: 193-198, 2011.

9. Scheen AJ, Beck E, De Flines J and Rorive M: Obesity, insulin resistance and type 2 diabetes: Risk factors for breast cancer. Rev Med Liege 66: 238-244, 2011 (In French)

10. Pandey A, Forte V, Abdallah M, Alickaj A, Mahmud S, Asad S and McFarlane SI: Diabetes mellitus and the risk of cancer. Minerva Endocrinol 36: 187-209, 2011.

11. Vigneri P, Frasca F, Sciacca L, Pandini G and Vigneri R: Diabetes and cancer. Endocr Relat Cancer 16: 1103-1123, 2009.

12. Chen TW, Liang YN, Feng D, Tao LY, Qi K, Zhang HY, Wang HX, Lin QS and Kong H: Metformin inhibits proliferation and promotes apoptosis of HER2 positive breast cancer cells by downregulating HSP90. J BUON 18: 51-56, 2013.

13. Col NF, Ochs L, Springmann V, Aragaki AK and Chlebowski RT: Metformin and breast cancer risk: A meta-analysis and critical literature review. Breast Cancer Res Treat 135: 639-646, 2012.

14. Jalving M, Gietema JA, Lefrandt JD, de Jong S, Reyners AK, Gans RO and de Vries EG: Metformin: Taking away the candy for cancer. Eur J Cancer 46: 2369-2380, 2010.

15. Bodmer M, Meier C, Krähenbühl S, Jick SS and Meier CR: Long-term metformin use is associated with decreased risk of breast cancer. Diabetes Care 33: 1304-1308, 2010.

16. Liu B, Fan Z, Edgerton SM, Deng XS, Alimova IN, Lind SE and Thor AD: Metformin induces unique biological and molecular responses in triple negative breast cancer cells. Cell Cycle 8: 2031-2040, 2009.

17. Alimova IN, Liu B, Fan Z, Edgerton SM, Dillon T, Lind SE and Thor AD: Metformin inhibits breast cancer cell growth, colony formation and induces cell cycle arrest in vitro. Cell Cycle 8 909-915, 2009

18. Song CW, Lee H, Dings RP, Williams B, Powers J, Santos TD, Choi BH and Park HJ: Metformin kills and radiosensitizes cancer cells and preferentially kills cancer stem cells. Sci Rep 2: 362, 2012.

19. Soga M, Ohashi A, Taniguchi M, Matsui T and Tsuda T: The di-peptide Trp-His activates AMP-activated protein kinase and enhances glucose uptake independently of insulin in L6 myotubes. FEBS Open Bio 4: 898-904, 2014.

20. Zhuang Y and Miskimins WK: Cell cycle arrest in Metformin treated breast cancer cells involves activation of AMPK, downregulation of cyclin D1, and requires $\mathrm{p} 27 \mathrm{Kip} 1$ or $\mathrm{p} 21 \mathrm{Cip} 1$. J Mol Signal 3: 18, 2008

21. Hadad SM, Fleming S and Thompson AM: Targeting AMPK: A new therapeutic opportunity in breast cancer. Crit Rev Oncol Hematol 67: 1-7, 2008.

22. Zong M, Fan DD, Lin S, Song YP, Wang ZY, Ma XL, Qiu WH, Bai YH, Li L and Li S: Anti-cancer activity and potential mechanism of a novel aspirin derivative. Eur J Pharmacol 791: 137-146, 2016.

23. Aban M, Siddqui I, Saboor M,Pervez S and Moatter T: Haplotypes of SNPs associated with COX-2 and their comparison with histopathological features of breast cancer patients. J Immuno Ther Cancer 3: 9, 2015.

24. Dhakal HP, Naume B, Synnestvedt M, Borgen E, Kaaresen R, Schlichting E, Wiedswang G, Bassarova A, Holm R, Giercksky KE and Nesland JM: Expression of cyclooxygenase-2 in invasive breast carcinomas and its prognostic impact. Histol Histopathol 27: 1315-1325, 2012.

25. Holmes MD, Chen WY, Schnitt SJ, Collins L, Colditz GA, Hankinson SE and Tamimi RM: COX-2 expression predicts worse breast cancer prognosis and does not modify the association with aspirin. Breast Cancer Res Treat 130: 657-662, 2011.

26. Ciris IM, Bozkurt KK, Baspinar S and Kapucuoğlu FN Immunohistochemical COX-2 overexpression correlates with HER-2/neu overexpression in invasive breast carcinomas: A pilot study. Pathol Res Pract 207: 182-187, 2011.

27. Kim HS, Moon HG, Han W, Yom CK, Kim WH, Kim JH and Noh DY: COX2 overexpression is a prognostic marker for Stage III breast cancer. Breast Cancer Res Treat 132: 51-59, 2012 .
28. Daneau G, Boidot R, Martinive P and Feron O: Identification of cyclooxygenase- 2 as a major actor of the transcriptomic adaptation of endothelial and tumor cells to cyclic hypoxia: Effect on angiogenesis and metastases. Clin Cancer Res 16: 410-419, 2010.

29. Lyons TR, Borges VF, Betts CB, Guo Q, Kapoor P, Martinson HA, Jindal S and Schedin P: Cyclooxygenase-2-dependent lymphangiogenesis promotes nodal metastasis of postpartum breast cancer. J Clin Invest 124: 3901-3912, 2014.

30. Killian PH, Kronski E, Michalik KM, Barbieri O, Astigiano S, Sommerhoff CP, Pfeffer U, Nerlich AG and Bachmeier BE: Curcumin inhibits prostate cancer metastasis in vivo by targeting the inflammatory cytokines CXCL1 and -2. Carcinogenesis 33: 2507-2519, 2012.

31. Karavitis J, Hix LM, Shi YH, Schultz RF, Khazaie K and Zhang M: Regulation of COX2 expression in mouse mammary tumor cells controls bone metastasis and PGE2-induction of regulatory T cell migration. PLoS One 7: e46342, 2012.

32. Lucci A, Krishnamurthy S, Singh B, Bedrosian I, Meric-Bernstam F, Reuben J, Broglio K, Mosalpuria K, Lodhi A, Vincent L and Cristofanilli M: Cyclooxygenase-2 expression in primary breast cancers predicts dissemination of cancer cells to the bone marrow. Breast Cancer Res Treat 117: 61-68, 2009.

33. Visscher DW, Pankratz VS, Santisteban M, Reynolds C, Ristimäki A, Vierkant RA, Lingle WL, Frost MH and Hartmann LC: Association between cyclooxygenase-2 expression in atypical hyperplasia and risk of breast cancer. J Natl Cancer Inst 100: 421-427, 2008.

34. Thun MJ, Henley SJ and Patrono C: Nonsteroidal anti-inflammatory drugs as anticancer agents: Mechanistic, pharmacologic, and clinical issues. J Natl Cancer Inst 94: 252-266, 2002.

35. Luchetti CG, Mikó E, Szekeres-Bartho J, Paz DA and Motta AB: Dehydroepiandrosterone and metformin modulate progesterone-induced blocking factor (PIBF), cyclooxygenase 2 (COX2) and cytokines in early pregnant mice. J Steroid Biochem Mol Biol 111: 200-207, 2008

36. Elia E, Sander V, Luchetti CG, Solano ME, Di Girolamo G, Gonzalez C and Motta AB: The mechanisms involved in the action of metformin in regulating ovarian function in hyperandrogenized mice. Mol Hum Reprod 12: 475-481, 2006.

37. Sobin LH and Compton CC: TNM seventh edition: What's new, what's changed: Communication from the international union against cancer and the American Joint Committee on Cancer. Cancer 116: 5336-5339, 2010.

38. Sabit H, Abdel-Ghany SE, M Said OA, Mostafa MA and El-Zawahry M: Metformin reshapes the methylation profile in breast and colorectal cancer cells. Asian Pac J Cancer Prev 19: 2991-2999, 2018.

39. Yue W, Zheng X, Lin Y, Yang CS, Xu Q, Carpizo D, Huang H, DiPaola RS and Tan XL: Metformin combined with aspirin significantly inhibit pancreatic cancer cell growth in vitro and in vivo by suppressing anti-apoptotic proteins Mcl-1 and Bcl-2. Oncotarget 6: 21208-21224, 2015.

40. Hodges V, Tucci M and Benghuzzi $\mathrm{H}$ : The effects of metformin and EGCG on PANC-1 cell survival. Biomed Sci Instrum 51: 393-399, 2015.

41. Liu K, Wang G, Ding H, Chen Y, Yu G and Wang J: Downregulation of metastasis suppressor 1(MTSS1) is associated with nodal metastasis and poor outcome in Chinese patients with gastric cancer. BMC Cancer 10: 428, 2010.

42. Livak KJ and Schmittgen TD: Analysis of relative gene expression data using real-time quantitative PCR and the 2(-Delta Delta C(T)) method. Methods 25: 402-408, 2001

43. Pollak M: Insulin and insulin-like growth factor signalling in neoplasia. Nat Rev Cancer 8: 915-928, 2008.

44. Hwang JT, Ha J, Park IJ, Lee SK, Baik HW, Kim YM and Park OJ: Apoptotic effect of EGCG in HT-29 colon cancer cells via AMPK signal pathway. Cancer Lett 247: 115-121, 2007.

45. Zakikhani M, Dowling R, Fantus IG, Sonenberg N and Pollak M Metformin is an AMP kinase-dependent growth inhibitor for breast cancer cells. Cancer Res 66: 10269-10273, 2006.

46. Morgensztern D and McLeod HL: PI3K/Akt/mTOR pathway as a target for cancer therapy. Anticancer Drugs 16: 797-803, 2005.

47. Okubo K, Isono M, Asano $\mathrm{T}$ and Sato A: Metformin augments Panobinostat's Anti-bladder cancer activity by activating AMP-activated protein kinase. Transl Oncol 12: 669-682, 2019.

48. Lipscombe LL, Goodwin PJ, Zinman B, McLaughlin JR and Hux JE: Diabetes mellitus and breast cancer: A retrospective population-based cohort study. Breast Cancer Res Treat 98: 349-356, 2006 
49. Dowling RJ, Niraula S, Stambolic V and Goodwin PJ: Metformin in cancer: Translational challenges. J Mol Endocrinol 48: R31-R43, 2012.

50. Chen X, Li C, He T, Mao J, Li C, Lyu J and Meng QH: Metformin inhibits prostate cancer cell proliferation, migration, and tumor growth through upregulation of PEDF expression. Cancer Biol Ther 17: 507-514, 2016.

51. Cantrell LA, Zhou C, Mendivil A, Malloy KM, Gehrig PA and Bae-Jump VL: Metformin is a potent inhibitor of endometrial cancer cell proliferation-implications for a novel treatment strategy. Gynecol Oncol 116: 92-98, 2010.

52. Iglesias DA, Yates MS, van der Hoeven D, Rodkey TL, Zhang Q, Co NN, Burzawa J, Chigurupati S, Celestino J, Bowser J, et al: Another surprise from Metformin: Novel mechanism of action via K-Ras influences endometrial cancer response to therapy. Mol Cancer Ther 12: 2847-2856, 2013.

53. Sarfstein R, Friedman Y, Attias-Geva Z, Fishman A, Bruchim I and Werner $\mathrm{H}$ : Metformin downregulates the insulin/IGF-I signaling pathway and inhibits different uterine serous carcinoma (USC) cells proliferation and migration in p53-dependent or -independent manners. PLoS One 8: e61537, 2013.

54. Zhou Y, Xu JN, Zeng C, Li X, Zhou YF, Qi Y and Xue Q: Metformin suppresses prostaglandin E2-induced cytochrome P450 aromatase gene expression and activity via stimulation of AMP-activated protein kinase in human endometriotic stromal cells. Reprod Sci 22: 1162-1170, 2015.

55. Bansal K, Narayana $\mathrm{Y}$ and Balaji KN: Inhibition of TNF-alpha-induced cyclooxygenase-2 expression by Mycobacterium bovis BCG in human alveolar epithelial A549 cells. Scand J Immunol 69: 11-19, 2009.

56. Zidar N, Odar K, Glavac D, Jerse M, Zupanc T and Stajer D: Cyclooxygenase in normal human tissues-is COX-1 really a constitutive isoform, and COX-2 an inducible isoform. J Cell Mol Med 13: 3753-3763, 2009.

57. Rodrigues S, Bruyneel E, Rodrigue CM, Shahin E and Gespach C: Cyclooxygenase 2 and carcinogenesis. Bull Cancer 91 Spec No: S61-S76, 2004 (In French).

58. Jørgensen SB, Jensen TE and Richter EA: Role of AMPK in skeletal muscle gene adaptation in relation to exercise. Appl Physiol Nutr Metab 32: 904-911, 2007.

59. Röckl KS, Witczak CA and Goodyear LJ: Signaling mechanisms in skeletal muscle: Acute responses and chronic adaptations to exercise. IUBMB Life 60: 145-153, 2008.

60. Huang SP, Wu MS, Shun CT, Wang HP, Hsieh CY, Kuo ML and Lin JT: Cyclooxygenase-2 increases hypoxia-inducible factor-1 and vascular endothelial growth factor to promote angiogenesis in gastric carcinoma. J Biomed Sci 12: 229-241, 2005.

61. Cianchi F, Cortesini C, Bechi P, Fantappiè O, Messerini L, Vannacci A, Sardi I, Baroni G, Boddi V, Mazzanti R and Masini E: Up-regulation of cyclooxygenase 2 gene expression correlates with tumor angiogenesis in human colorectal cancer. Gastroenterology 121: 1339-1347, 2001.
62. Hadad SM, Baker L, Quinlan PR, Robertson KE, Bray SE, Thomson G, Kellock D, Jordan LB, Purdie CA, Hardie DG, et al: Histological evaluation of AMPK signalling in primary breast cancer. BMC Cancer 9: 307, 2009.

63. Zhang T, Wang X, He D, Jin X and Guo P: Metformin sensitizes human bladder cancer cells to TRAIL-induced apoptosis through mTOR/S6K1-mediated downregulation of c-FLIP. Anticancer Drugs 25: 887-897, 2014.

64. Takabatake M, Daino K, Imaoka T, Nishimura M, Morioka T, Fukushi $M$ and Shimada Y: Aberrant expression and phosphorylation of 4E-BP1, a main target of mTOR signaling, in rat mammary carcinomas: an association with etiology. In Vivo 25: 853-860, 2011.

65. Coleman LJ, Peter MB, Teall TJ, Brannan RA, Hanby AM, Honarpisheh H, Shaaban AM, Smith L, Speirs V, Verghese ET, et al: Combined analysis of eIF4E and 4E-binding protein expression predicts breast cancer survival and estimates eIF4E activity. Br J Cancer 100: 1393-1399, 2009.

66. Akcakanat A, Sahin A, Shaye AN, Velasco MA and Meric-Bernstam F: Comparison of Akt/mTOR signaling in primary breast tumors and matched distant metastases. Cancer 112: 2352-2358, 2008.

67. Bort A, Quesada S, Ramos-Torres Á, Gargantilla M, Priego EM, Raynal S, Lepifre F, Gasalla JM, Rodriguez-Henche N, Castro A and Díaz-Laviada I: Identification of a novel 2-oxindole fluorinated derivative as in vivo antitumor agent for prostate cancer acting via AMPK activation. Sci Rep 8: 4370, 2018.

68. Rehman G, Shehzad A, Khan AL and Hamayun M: Role of AMP-activated protein kinase in cancer therapy. Arch Pharm (Weinheim) 347: 457-468, 2014.

69. Lee MS, Han HJ, Han SY, Kim IY, Chae S, Lee CS, Kim SE, Yoon SG, Park JW, Kim JH, et al: Loss of the E3 ubiquitin ligase MKRN1 represses diet-induced metabolic syndrome through AMPK activation. Nat Commun 9: 3404, 2018.

70. Janzen NR, Whitfield $J$ and Hoffman NJ: Interactive roles for AMPK and glycogen from cellular energy sensing to exercise metabolism. Int J Mol Sci 19: 3344, 2018.

71. Jiralerspong S, Palla SL, Giordano SH, Meric-Bernstam F, Liedtke C, Barnett CM, Hsu L, Hung MC, Hortobagyi GN and Gonzalez-Angulo AM: Metformin and pathologic complete responses to neoadjuvant chemotherapy in diabetic patients with breast cancer. J Clin Oncol 27: 3297-3302, 2009.

This work is licensed under a Creative Commons Attribution-NonCommercial-NoDerivatives 4.0 International (CC BY-NC-ND 4.0) License. 